\title{
Aerosol radiative effects in the ultraviolet, visible, and near-infrared spectral ranges using long-term aerosol data series over the Iberian Peninsula
}

\author{
D. Mateos ${ }^{1,2}$, M. Antón ${ }^{1}$, C. Toledano ${ }^{2}$, V. E. Cachorro ${ }^{2}$, L. Alados-Arboledas ${ }^{3,4}$, M. Sorribas ${ }^{3,4,5}$, M. J. Costa ${ }^{6}$, and \\ J. M. Baldasano ${ }^{7}$ \\ ${ }^{1}$ Departamento de Física, Universidad de Extremadura, Badajoz, Spain \\ ${ }^{2}$ Grupo de Óptica Atmosférica, Universidad de Valladolid, Valladolid, Spain \\ ${ }^{3}$ Departamento de Física Aplicada, Universidad de Granada, Granada, Spain \\ ${ }^{4}$ Andalusian Institute for Earth System Research, Universidad de Granada, Granada, Spain \\ ${ }^{5}$ Estación de Sondeos Atmosféricos El Arenosillo, INTA, Huelva, Spain \\ ${ }^{6}$ Évora Geophysics Centre and Dep. Physics, University of Évora, Évora, Portugal \\ ${ }^{7}$ Universidad Politécnica de Cataluña, Barcelona, Spain \\ Correspondence to: D. Mateos (mateos@goa.uva.es)
}

Received: 14 February 2014 - Published in Atmos. Chem. Phys. Discuss.: 2 April 2014

Revised: 10 November 2014 - Accepted: 14 November 2014 - Published: 19 December 2014

\begin{abstract}
A better understanding of aerosol radiative properties is a crucial challenge for climate change studies. This study aims at providing a complete characterization of aerosol radiative effects in different spectral ranges within the shortwave (SW) solar spectrum. For this purpose, longterm data sets of aerosol properties from six AERONET stations located in the Iberian Peninsula (southwestern Europe) have been analyzed in terms of climatological characterization and inter-annual changes. Aerosol information was used as input for the libRadtran model in order to determine the aerosol radiative effect (ARE) at the surface in the ultraviolet (ARE $E_{U V}$ ), visible (ARE $E_{V I S}$ ), near-infrared $\left(A R E_{N I R}\right)$, and the entire $S W$ range $\left(A R E_{S W}\right)$ under cloudfree conditions. Over the whole Iberian Peninsula, yearly aerosol radiative effects in the different spectral ranges were found to be $-1.1<\mathrm{ARE}_{\mathrm{UV}}<-0.7,-5.7<\mathrm{ARE}_{\mathrm{VIS}}<-3.5$, $-2.6<\mathrm{ARE}_{\mathrm{NIR}}<-1.6$, and $-8.8<\mathrm{ARE}_{\mathrm{SW}}<-5.7$ (in $\mathrm{W} \mathrm{m}^{-2}$ ). Monthly means of ARE showed a seasonal pattern with larger values in spring and summer. The aerosol forcing efficiency (AFE), ARE per unit of aerosol optical depth, has also been evaluated in the four spectral ranges. AFE exhibited a dependence on single scattering albedo as well as a weaker one on the Angström exponent. AFE is larger (in absolute value) for small and absorbing particles. The contributions of the UV, VIS, and NIR ranges to the SW
\end{abstract}

efficiency varied with the aerosol types. The predominant aerosol size determined the fractions $\mathrm{AFE}_{\mathrm{VIS}} / \mathrm{AFE}_{\mathrm{SW}}$ and $\mathrm{AFE}_{\mathrm{NIR}} / \mathrm{AFE}_{\mathrm{SW}}$. The $\mathrm{AFE}_{\mathrm{VIS}}$ was the dominant contributor for all aerosol types, although non-absorbing large particles caused more even contribution of VIS and NIR intervals. The $\mathrm{AFE}_{\mathrm{UV}} / \mathrm{AFE}_{\mathrm{SW}}$ ratio showed a higher value in the case of absorbing fine particles.

\section{Introduction}

Atmospheric aerosol particles can absorb and scatter part of the total amount of solar radiation entering the Earth's atmosphere. Aerosols directly influence the Earth's energy budget and act as cloud condensation nuclei modifying the cloud structure (e.g., Boucher et al., 2013). Aerosols can either be produced by ejection into the atmosphere or by physical and chemical processes within the atmosphere. Aerosol particles affect the radiative field by attenuating the direct component, thereby enhancing (or reducing under a highly absorbing aerosol) the diffuse component. They also produce indirect effects by perturbing the Earth's atmospheric radiative balance by modulating cloud albedo and fraction. 
The aerosol radiative effect (ARE) is defined as the change in net radiation due to changes in atmospheric aerosol properties and content. This is a key quantity in the determination of climate change (e.g., Hansen et al., 1998). Most studies dealing with ARE have focused on discrete wavelengths, whole shortwave (SW) solar radiation spectrum (e.g., Rajeev and Ramanathan, 2001; García et al., 2008; di Sarra et al., 2008; Foyo-Moreno et al., 2014; Mateos et al., 2013a), longwave (LW) radiation (e.g., Panicker et al., 2008; di Sarra et al., 2011; Antón et al., 2014), ultraviolet (UV) interval (e.g., Hatzianastassiou et al., 2004; Kazadzis et al., 2009; Nikitidou et al., 2013), and visible (VIS) range (e.g., Jayaraman et al., 1998; Horvath et al., 2002; Bush and Valero, 2003; Meloni et al., 2003). With regards to surface SW radiative effect (ARE $\mathrm{AW}_{\mathrm{S}}$, Di Biagio et al. (2010) obtained the maximum radiative daily effects for different aerosol types in the central Mediterranean in the period 2004-2007: $-61 \mathrm{~W} \mathrm{~m}^{-2}$ (desert dust aerosols), $-26 \mathrm{~W} \mathrm{~m}^{-2}$ (urban/industrial-biomass burning aerosols), and $-43 \mathrm{~W} \mathrm{~m}^{-2}$ (mixed aerosols). All these negative figures point out a cooling of the Earth's surface. Aerosol radiative effects in the $\mathrm{LW}$ range $\left(\mathrm{ARE}_{\mathrm{LW}}\right)$ for dust particles are expected to be smaller than in the SW and with a positive sign (see, e.g., di Sarra et al., 2011; Antón et al., 2014). Hence, this heating effect at the surface can partly offset the cooling induced in the SW range. With respect to the ARE for the UV range (ARE $\mathrm{AV}_{\mathrm{UV}}$ ), Nikitidou et al. (2013) analyzed the ARE in two different spectral regions in the UV range: $300-315$ and $315-360 \mathrm{~nm}$. They found a stronger attenuation in the UVB than in the UVA.

The main goal of this study is to evaluate the ARE at the surface over the Iberian Peninsula, which is a region of great interest because of its geographical position in southwestern Europe, near the African continent and the interface between the Atlantic Ocean and the Mediterranean basin. Thus, it is affected by frequent desert dust intrusions which modulate the aerosol climatology of the Iberian Peninsula (Toledano et al., 2007a, Bennouna et al., 2011; Pey et al., 2013; Valenzuela et al., 2012). In addition, this area is also affected by a great variety of air masses loaded with different aerosol types: clean continental, polluted plumes of central Europe, and marine aerosols. Hence aerosol climatology at six stations (Palencia, Barcelona, Cabo da Roca, Évora, Granada, and El Arenosillo) is also carried out for different time periods between 2001 and 2012. Aerosol radiative effects and their efficiency are calculated in four regions of the solar spectrum (ultraviolet, visible, near-infrared, and shortwave), and the relative contribution of each range with respect to the whole solar spectrum is analyzed as a function of the aerosol properties. Therefore, this study is intended to contribute to the understanding of the aerosol impact on the radiative budget over the Iberian Peninsula.

This article presents the following outline: detailed descriptions of the aerosol stations and the database used are performed in Sect. 2; Sect. 3 includes the methodology; the results obtained in the different analyses about the cli- matology of aerosol properties, aerosol radiative effects, and aerosol forcing efficiencies are shown and discussed in Sects. 4, 5, and 6, respectively. Finally, the main conclusions of this article are summarized in Sect. 7.

\section{Columnar aerosol optical data}

The aerosol data are obtained from the Aerosol Robotic Network (AERONET) (Holben et al., 1998). Six AERONET sites operating in the Iberian Peninsula were selected in this study: Palencia, Barcelona, Évora, Cabo da Roca, Granada, and El Arenosillo (see Table 1), all of them with a minimum of 8 years of data sets of continuous observations. These sites present the largest records of aerosol properties in the Iberian Peninsula in the AERONET network.

The standard instrument used in AERONET is the Cimel CE318 radiometer. It performs direct sun measurements at several wavelengths in the spectral range $340-1020 \mathrm{~nm}$. Furthermore, the instrument also measures sky radiance in the solar almucantar and principal plane configurations at 440, 670,870 , and $1020 \mathrm{~nm}$ wavelengths. A detailed description of this instrument is provided by Holben et al. (1998). The direct sun observations are used to derive the spectral aerosol optical depth (AOD) and the corresponding Ångström exponent. The sky radiances, together with the AOD, are employed to retrieve a set of aerosol optical and microphysical properties via inversion methods (Dubovik and King, 2000; Dubovik et al., 2006). These include particle size distribution, complex refractive index, single scattering albedo (SSA), phase function, asymmetry parameter, fraction of non-spherical particles, etc. (see http://aeronet.gsfc.nasa.gov/ new_web/Documents/Inversion_products_V2.pdf). Data are provided in three database levels: 1.0 (raw data), 1.5 (cloudscreened), and 2.0 (cloud-screened and quality-assured).

The calibration of these instruments is performed following AERONET protocols by the AERONET-NASA, PHOTONS, and RIMA networks approximately every 12 months of operation. The estimated uncertainty is $0.01-0.02$ for AOD (larger at shorter wavelengths) and $\sim 5 \%$ for the sky radiances (Holben et al., 1998). The SSA has an absolute uncertainty of 0.03-0.07 depending on the aerosol load and type (Dubovik et al., 2000).

Level 2.0 aerosol optical depth data have been used in this work. However, it is well-known that when level 2.0 inversion data are used, the number of available observations of single scattering albedo (SSA) and asymmetry factor (g) is quite limited because these variables are only considered reliable when $\mathrm{AOD}_{440 \mathrm{~nm}}>0.4^{1}$. Such AOD is mainly reached in the study region during Saharan dust or biomass burning events; therefore we do not have information on SSA and $g$ for other conditions. To solve this issue, we have reduced the threshold of the

\footnotetext{
${ }^{1}$ Other inversion products, like the volume size distributions, are provided for all AOD levels.
} 
Table 1. Coordinates and time interval of the six AERONET sites used in this study.

\begin{tabular}{lcccc}
\hline Station & Latitude $\left({ }^{\circ} \mathrm{N}\right)$ & Longitude $\left({ }^{\circ} \mathrm{E}\right)$ & Altitude a.s.1. $(\mathrm{m})$ & Time interval \\
\hline Palencia & 41.99 & -4.52 & 750 & $2003-2011$ \\
Barcelona & 41.39 & 2.12 & 125 & $2004-2012$ \\
Cabo da Roca & 38.78 & -9.50 & 140 & $2003-2011$ \\
Évora & 38.57 & -7.91 & 293 & $2005-2012$ \\
Granada & 37.16 & -3.61 & 680 & $2004-2012$ \\
El Arenosillo & 37.11 & -6.73 & 0 & $2000-2009$ \\
\hline
\end{tabular}

level 2.0 inversion products. For this we started with the level 1.5 data (for those quality-assured almucantar data that reached level 2.0) and applied the same criteria used by AERONET to produce the level 2.0 data: the number of symmetrical angles, retrieval error, and solar zenith angle (see http://aeronet.gsfc.nasa.gov/new_web/Documents/ AERONETcriteria_final1_excerpt.pdf). However, a less restrictive threshold is applied to the AOD, which we restricted to cases with $\mathrm{AOD}_{440 \mathrm{~nm}}>0.15$ instead of 0.4 . This choice is considered a compromise between the amount and the quality of the data. This kind of approach has been adopted by other authors using AERONET absorption data (e.g., Mallet et al., 2013). The threshold of 0.15 seems adequate for analyzing the typical values of the AOD in the Iberian Peninsula (e.g., Bennouna et al., 2011; Obregón et al., 2012) because it can be considered a value of separate background aerosol conditions from episodic events with moderate or high aerosol loadings. The level 1.5-filtered data of SSA and $g$ are daily averaged in order to have one value per day. In these conditions, the estimated uncertainty of the single scattering albedo is $\pm 0.05-0.07$ (Dubovik et al., 2000). Furthermore, we tested the uncertainty of our approach for those days presenting both level 2.0 data and measurements in the 1.5-filtered level. We evaluated the difference in the SSA values of the level 1.5-filtered data with respect to the closest level 2.0 data. The mean relative differences in the SSA values between both methodologies are smaller than $1 \%$, being similar to the inversion uncertainty.

Lastly, when the AOD is low $(<0.15$ at $440 \mathrm{~nm})$ there is no reliable information on the absorption properties in the almucantar retrievals. Such low AOD is typical in our study region (e.g., almost $70 \%$ of observations at Palencia, Granada, and Évora are below this threshold). If only cases with $\mathrm{AOD}_{440 \mathrm{~nm}}>0.15$ are considered in our study, the derived aerosol radiative effect is unrealistically large. To overcome this problem of representativeness, fixed values of SSA (0.90) and $g(0.75)$ have been used for the cases with AOD $<0.15$ at $440 \mathrm{~nm}$, considering typical values for continental, desert, and maritime aerosols (e.g., Hess et al., 1998). In spite of the associated uncertainties, our approximation (daily level 1.5-filtered values of these aerosol properties for AOD > 0.15 together with a typical fixed value for low AOD cases) provides a good characterization of the aerosol ab- sorption of the particles present in the atmosphere. The data products and AERONET database level are summarized in Table 2, where the estimated absolute uncertainties of AOD and SSA are also provided.

\section{Methodology}

The ARE calculations are performed in the ultraviolet $\left(\mathrm{ARE}_{\mathrm{UV}}, 280-400 \mathrm{~nm}\right)$, visible (AREVIS, 400-700 nm), near-infrared $\left(\mathrm{ARE}_{\mathrm{NIR}}, 700-2800 \mathrm{~nm}\right)$, and shortwave $\left(\mathrm{ARE}_{\mathrm{SW}}, 280-2800 \mathrm{~nm}\right.$ ) intervals. For this purpose, cloudfree simulations are carried out by means of a radiative transfer code.

The libRadtran model (Mayer and Kylling, 2005) has been shown to be a useful tool for obtaining solar radiation data, presenting high accuracy (e.g., Román et al., 2014). Version 1.7 of the libRadtran is used in this study with inputs of aerosol, total ozone column (TOC), precipitable water vapor column (PWC), and surface albedo data. We performed simulations of ultraviolet $(280-400 \mathrm{~nm})$, visible $(400-700 \mathrm{~nm})$, near-infrared $(700-2800 \mathrm{~nm})$, and shortwave $(280-2800 \mathrm{~nm})$ radiation during the periods indicated in Table 1 . Total ozone column is provided by the Ozone Monitoring Instrument (OMI) and Total Ozone Mapping Spectrometer (TOMS). Daily values of these instruments are obtained from the Level-3 Daily Global gridded products, which are downloaded using the Giovanni application (http://disc.sci.gsfc. nasa.gov/giovanni). Level 2.0 AERONET PWC data are used in the calculations. The uncertainty of this parameter is 10 $15 \%$ (Holben et al., 1998). In addition, retrievals of surface albedo at 440, 675, 870, and $1020 \mathrm{~nm}$ from the AERONET algorithm are also used in this work. For land surface cover, this algorithm relies on the Lie-Ross model (Lucht and Roujean, 2000) while considering the bidirectional reflectance distributions from MODIS (Moody et al., 2005).

Aerosol properties obtained from AERONET measurements are also used as input for the libRadtran model. Ångström coefficients $\alpha$ and $\beta$ are utilized to compute a spectral aerosol optical depth in the wavelengths of interest (Schuster et al., 2006). The Ångström exponent $\alpha$ is obtained with the measurements between 440 and $870 \mathrm{~nm}$, while the turbidity $\beta$ is obtained from the $\alpha$ value and aerosol data at $1020 \mathrm{~nm}$. Since the aerosol asymmetry factor, single 
Table 2. Summary of AERONET data used for ARE calculations: aerosol optical depth (AOD), single scattering albedo (SSA), asymmetry factor $(g)$, precipitable water vapor column (PWC). Estimated absolute uncertainty of AOD and SSA is given according to Dubovik et al. (2002) and PWC error according to Holben et al. (1998).

\begin{tabular}{llr}
\hline & AERONET database & Estimated uncertainty \\
\hline AOD & Level 2.0 & $\pm 0.01-0.02$ \\
SSA, $g\left(\mathrm{AOD}_{440}>0.4\right)$ & Level 2.0 & \pm 0.03 (in SSA) \\
SSA, $g\left(0.15<\mathrm{AOD}_{440}<0.4\right)$ & Level 1.5-filtered* & $\pm 0.05-0.07$ (in SSA) \\
SSA, $g\left(\mathrm{AOD}_{440}<0.15\right)$ & Fixed value & \\
PWC & Level 2.0 & $10-15 \%$ \\
\hline
\end{tabular}

*Filters applied are the same as in level 2.0 except for $\mathrm{AOD}_{440}$ (see text).

Table 3. AFE values and their standard error for the UV, VIS, NIR, and SW ranges for, separately, four SSA and three $\alpha$ intervals over the Iberian Peninsula. Units are $\mathrm{Wm}^{-2} \tau^{-1}$. SSA groups: $0.85 \geq \mathrm{SSA}_{1}>0.80$ (group 1), $0.90 \geq \mathrm{SSA}_{2}>0.85$ (group 2 ), $0.95 \geq \mathrm{SSA}_{3}>0.90$ (group 3), and $1.0 \geq \mathrm{SSA}_{4}>0.95$ (group 4); and $\alpha$ groups: $0 \leq \alpha_{1} \leq 1$ (group 1), $1.0 \leq \alpha_{2} \leq 1.5$ (group 2), and $1.5<\alpha_{3} \leq 2$ (group 3 ). The average values without any classification are also presented.

\begin{tabular}{lcrrrr}
\hline Variable & Group & AFE $_{\mathrm{UV}}$ & AFE $_{\mathrm{VIS}}$ & AFE $_{\mathrm{NIR}}$ & AFE $_{\mathrm{SW}}$ \\
\hline \multirow{2}{*}{$\alpha$} & 1 & $-5.41 \pm 0.06$ & $-30.1 \pm 0.3$ & $-20.9 \pm 0.2$ & $-56.5 \pm 0.5$ \\
& 2 & $-6.60 \pm 0.09$ & $-38.3 \pm 0.4$ & $-19.1 \pm 0.2$ & $-64.0 \pm 0.6$ \\
& 3 & $-7.06 \pm 0.10$ & $-39.4 \pm 0.4$ & $-16.9 \pm 0.2$ & $-63.3 \pm 0.7$ \\
\hline \multirow{2}{*}{ SSA } & 1 & $-9.7 \pm 0.2$ & $-52.8 \pm 0.8$ & $-24.9 \pm 0.5$ & $-87.4 \pm 1.4$ \\
& 2 & $-8.19 \pm 0.10$ & $-44.6 \pm 0.4$ & $-21.2 \pm 0.2$ & $-74.0 \pm 0.6$ \\
& 3 & $-6.37 \pm 0.05$ & $-35.9 \pm 0.2$ & $-19.5 \pm 0.2$ & $-61.8 \pm 0.3$ \\
Average & 4 & $-4.59 \pm 0.05$ & $-26.6 \pm 0.2$ & $-18.1 \pm 0.2$ & $-49.3 \pm 0.3$ \\
\hline
\end{tabular}

scattering albedo, and surface albedo are obtained at four wavelengths from AERONET in each measurement, three different spectral regions are simulated with the libRadtran model. For computations in the UV range $(280-400 \mathrm{~nm})$, the AERONET retrievals of aerosol asymmetry factor, aerosol single scattering albedo, and surface albedo at $440 \mathrm{~nm}$ are used. The AERONET retrievals at $675 \mathrm{~nm}$ of the same variables are used in the visible range $(400-700 \mathrm{~nm})$, while in the near-infrared region $(700-2800 \mathrm{~nm})$ we used the average properties retrieved at 870 and $1020 \mathrm{~nm}$. In each interval, these properties are considered wavelength-independent. This choice to perform the radiative transfer simulations is proven as adequate in Appendix A. Other options in the model setup are as follows: extraterrestrial irradiance values are taken from Gueymard (2004); profiles of temperature, air density, ozone, and other atmospheric gases are taken from the midlatitude summer/winter standard atmospheres; and the radiative equation solver is the improved version of the discrete ordinate method of Stamnes et al. (2000) (DISORT2) calculated by 16-streams (e.g., de Miguel et al., 2011). After computing the solar irradiance in the different spectral intervals, the SW irradiance is evaluated by adding up the contributions of these three spectral regions.

In order to evaluate the aerosol radiative effect, the simulations under aerosol-free conditions are also computed with the same inputs as explained above but with a fixed $\beta$ value of 0.001 . The use of radiative transfer models fed with reliable experimental aerosol data to determine the ARE has also been employed in other studies (e.g., Barja and Antuña, 2011; Valenzuela et al., 2012; García et al., 2014).

Once the simulated radiometric values are obtained, ARE is derived for each interval (X represents UV, VIS, NIR, and $\mathrm{SW})$ at the surface by:

$$
\operatorname{ARE}_{X}=\left(X_{\text {aer }}^{\downarrow}-X_{\text {aer }}^{\uparrow}\right)-\left(X_{\text {NOaer }}^{\downarrow}-X_{\text {NOaer }}^{\uparrow}\right)
$$

where $X_{\text {aer }}$ and $X_{\text {NOaer }}$ are the irradiances $\left(\mathrm{W} \mathrm{m}^{-2}\right)$ for the $X$ range under actual and aerosol-free conditions, respectively.

Daily values are obtained by the integration of the hourly data during the whole day $(24 \mathrm{~h})$, considering $\mathrm{ARE}=0 \mathrm{~W} \mathrm{~m}^{-2}$ for $\mathrm{SZA}>90^{\circ}$ (e.g., Bush and Valero, 2003; Valenzuela et al., 2012) and assuming cloud-free conditions during the day:

$$
\mathrm{ARE}_{\text {daily }}=\sum \mathrm{ARE}_{\text {hourly }} \frac{\mathrm{d} t}{24}
$$

The aerosol forcing efficiency (AFE) is defined as the rate at which the radiative effect varies per unit of AOD (e.g., Di Biagio et al., 2009 and the references therein). The linear relationship between aerosol radiative effect and AOD is well 


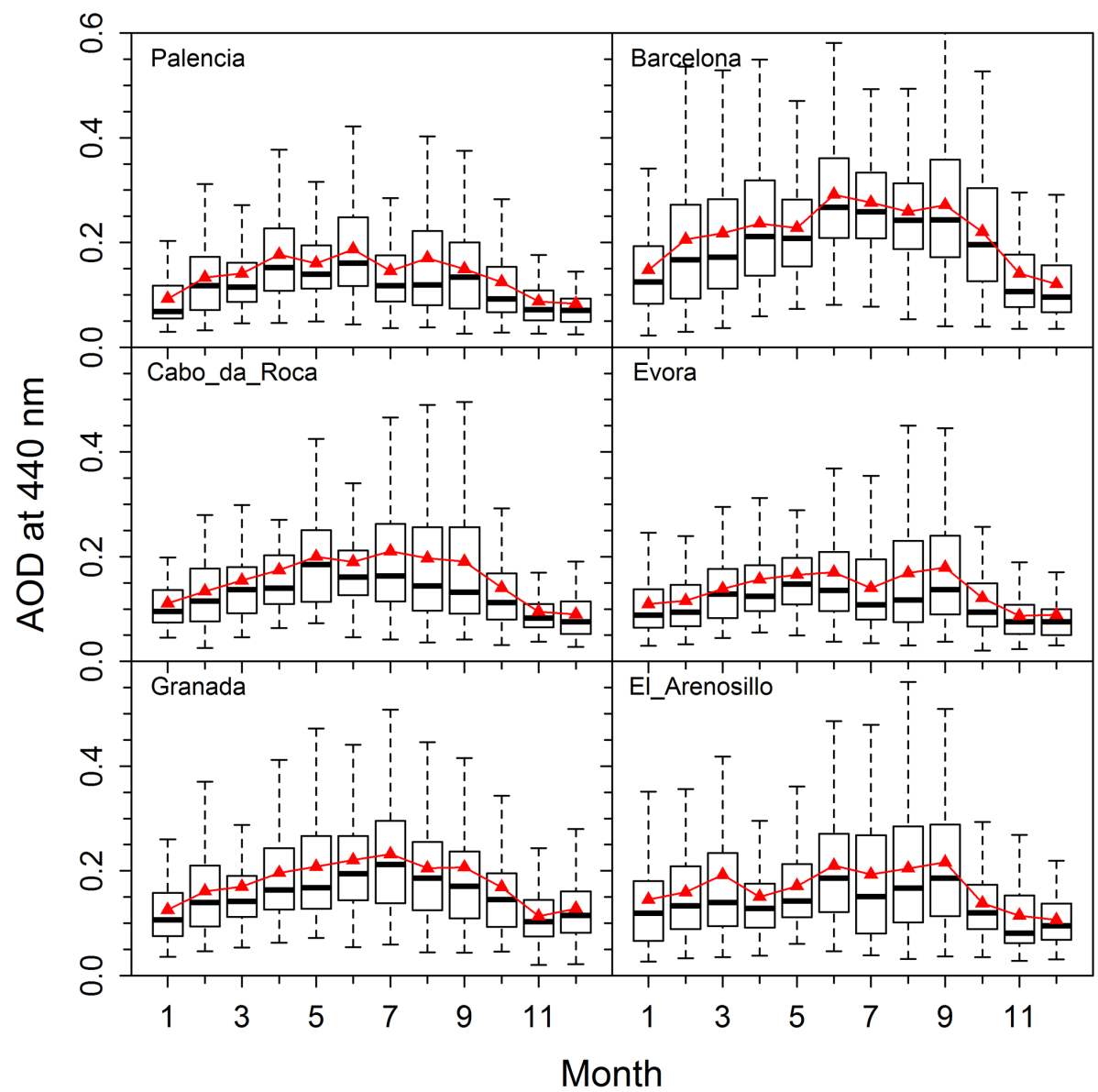

Figure 1. Annual cycle of daily values of AOD at $440 \mathrm{~nm}$ in box whisker plots for the six sites studied. Triangles and horizontal solid lines indicate the monthly average and median values, respectively.

known (see, e.g., Costa et al., 2004, 2006; Di Biagio et al., 2009). Hence, in this study, ARE is obtained as the slope of linear fits in the ARE vs. AOD $500 \mathrm{~nm}$ relationships. Therefore $\mathrm{AFE}$ values are expressed in $\mathrm{W} \mathrm{m}^{-2}$ per $\mathrm{AOD}_{500 \mathrm{~nm}}$-unit $\left(\mathrm{Wm}^{-2} \tau^{-1}\right)$.

With respect to the temporal trends calculated in this study, the Sen method (Sen, 1968) is applied to evaluate the slope of a time series using the Mann-Kendall non-parametric test to determine the significance of these rates. The Sen method is not greatly affected by outliers and can be computed when there are gaps in the database (Collaud Coen et al., 2013). This is a common and adequate method in temporal trend evaluation (e.g., Sánchez-Lorenzo et al., 2013). The trends calculated in this study are obtained in the corresponding physical units per year. However, to unify notation with previous studies dealing with the radiative effect trends of clouds and aerosols (e.g., Mateos et al., 2013b), the results are multiplied by 10 and expressed in physical units per decade. In this way, the rates are also easier to read.

\section{Analysis of aerosol properties over the Iberian Peninsula}

A direct Sun observation (AOD at $440 \mathrm{~nm}$ ) is selected to perform the climatological analysis because the estimations of $\mathrm{AOD}_{500 \mathrm{~nm}}$ (used in the ARE calculations) are obtained using $\alpha$ values. Thus we minimized the impact of other uncertainty sources in the AOD analysis. Besides, the results for $\mathrm{AOD}_{440 \mathrm{~nm}}$ and $\mathrm{AOD}_{500 \mathrm{~nm}}$ do not differ excessively. In order to identify the differences in the aerosol climatology over the six sites analyzed in this study, the monthly distribution of the daily values of the $\mathrm{AOD}_{440 \mathrm{~nm}}$ and $\alpha$ are evaluated using the database mentioned in Table 1. All the available level 2.0 AERONET measurements are used in this section.

Figure 1 shows the climatology of the aerosol load in box whisker plots. Several conclusions can be drawn from this figure. The highest values of the AOD occur in Barcelona, as can be expected because it is a large city. With respect to the monthly average values (triangles in the figure), the central stations in the Iberian Peninsula (Palencia and Évora) exhibit $\mathrm{AOD}_{440 \mathrm{~nm}}$ below 0.2, while the southern sites (Cabo 


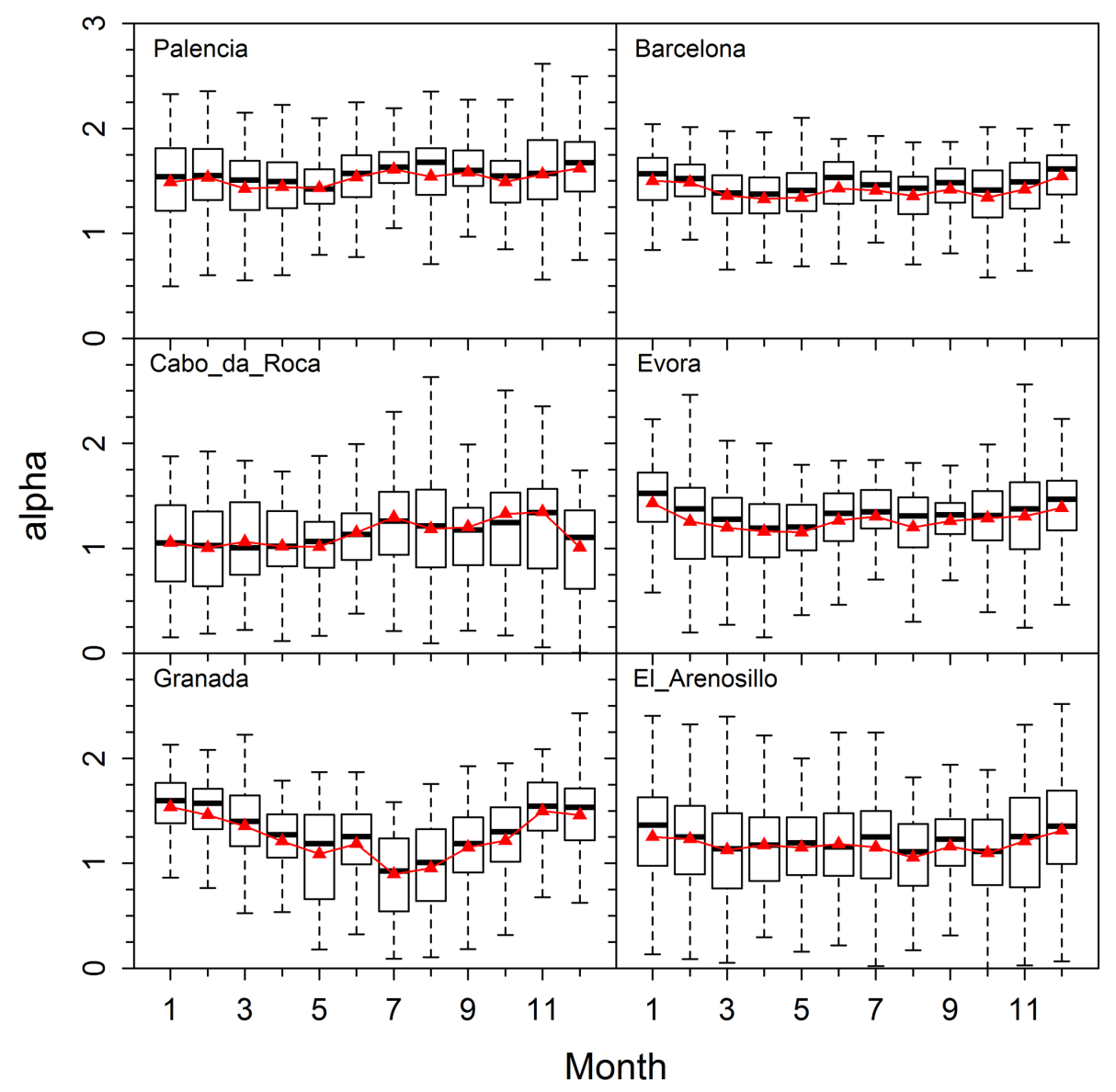

Figure 2. Annual cycle of daily values of $\alpha$ ("alpha" in the figure) in box whisker plots for the six sites studied. Triangles and horizontal solid lines indicate the monthly average and median values, respectively.

da Roca, Granada, and El Arenosillo) show aerosol load over 0.2 during summer months. The $\mathrm{AOD}_{440 \mathrm{~nm}}$ seasonal distribution is shown with maximum values in summer and minimum ones in winter. However, the seasonality becomes more evident in the stations outside the central area of the Iberian Peninsula. The large differences between median and average values for some months are evidence of a large impact of high aerosol optical depth events on the monthly climatology. Similarly, the bimodality of the monthly AOD climatology (with two maximum monthly means occurring in March and summer months) observed for the El Arenosillo site has already been reported by previous studies (e.g., Bennouna et al., 2011) and is directly attributed to desert dust intrusions from the African continent.

To go further in the characterization, $\alpha$ allows for a better understanding of the particle size over each site. Figure 2 shows the climatology of this variable over the six stations also using box whisker plots. In the analysis of the monthly average means, $\alpha$ values larger than one, indicative of the predominance of fine particles, are dominant over Barcelona, Palencia, and Évora. The other three stations (Cabo da Roca, Granada, and El Arenosillo) present monthly $\alpha$ averages over and below 1 , which means a larger variety of aerosol sizes over these stations. A seasonal dependence over the Granada site is seen, with winter months dominated by fine particles and summer months by larger ones (see also Navas-Guzman et al., 2013). Values of $\alpha$ present a large variability during summer, which is indicative of the influence of different aerosol types including biomass burning events and Saharan dust transport (e.g., Pérez-Ramírez, 2008). The monthly distribution of $\alpha$ is symmetric with similar average and median values throughout the year for the six sites.

With the daily AOD and $\alpha$ values it is possible to classify the origin of the aerosol particles. Previous studies suggest different thresholds of AOD and $\alpha$ (e.g., Hess et al., 1998; Pace et al., 2006; Toledano et al., 2007b). A simple classification of aerosol type, which can be used for the whole Iberian Peninsula, is carried out in this study. The threshold between fine and large particles is placed at $\alpha=1$, while the situations with a high aerosol load are those with $\mathrm{AOD}_{440 \mathrm{~nm}}>0.2$. Therefore, aerosol particles can be classified in four types: maritime $\left(\mathrm{AOD}_{440 \mathrm{~nm}}<0.2\right.$ and $\alpha<1$ ), desert dust ( $\mathrm{AOD}_{440 \mathrm{~nm}}>0.2$ and $\left.\alpha<1\right)$, continental clean $\left(\mathrm{AOD}_{440 \mathrm{~nm}}<0.2\right.$ and $\left.\alpha>1\right)$, and continental pol- 

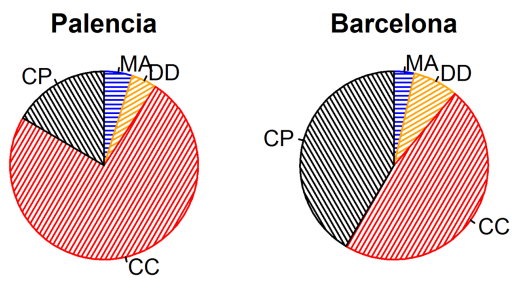

Evora

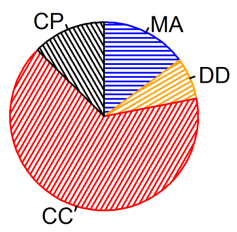

Granada

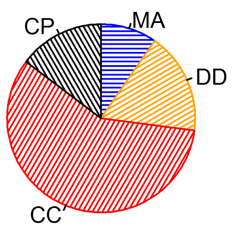

Cabo_da_Roca

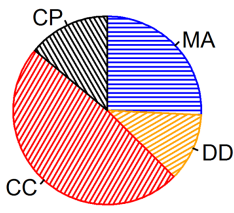

El_Arenosillo

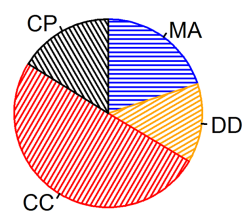

Figure 3. Relative frequency of aerosol type occurrence: maritime (MA), desert dust (DD), continental clean (CC), and continental polluted (CP) for the six sites studied.

luted $\left(\mathrm{AOD}_{440 \mathrm{~nm}}>0.2\right.$ and $\left.\alpha>1\right)$. Note that the limit of $\mathrm{AOD}_{440 \mathrm{~nm}}<0.2$ is arbitrary and this value could be adjusted according to the sites, which likely produce a different distribution in the pie diagrams. Even close stations can present slight differences in the $\alpha$-AOD classification (see, e.g., Obregón et al., 2012). However, it is not the aim of this work to provide an extensive aerosol climatology, but rather to demonstrate the great variety of air masses over Iberia which transport different aerosol types. Although other types, such as biomass burning or mixed aerosols, are placed in the boundaries of these types, this simple classification can provide information about the aerosol sources for the six sites. The classification used here is in line with the previous studies. For instance, Toledano et al. (2007b) proposed for the El Arenosillo site similar thresholds (see their Table V), although they identified continental polluted aerosols with an $\mathrm{AOD}_{440 \mathrm{~nm}}$ larger than 0.35 and $\alpha>1.4$. Pace et al. (2006) proposed (Central Mediterranean) a desert dust identification at Lampedusa island when $\mathrm{AOD}_{440 \mathrm{~nm}} \geq 0.15$ and $\alpha \leq 0.5$.

Figure 3 shows pie diagrams with the frequency of occurrence of the four aerosol types. The six diagrams agree, pointing at continental clean as the main type of aerosols over the Iberian Peninsula. In Barcelona there is also an important contribution of continental polluted, since Barcelona is a large coastal city with relevant pollution levels from vehicular and ship traffic (e.g., Reche et al., 2011). The influence of maritime aerosols is notable at the El Arenosillo, Cabo da Roca, and Évora sites (see also, e.g., Bennouna et al., 2011; Obregón et al., 2012). Furthermore, desert dust events are shown to be common in the Iberian Peninsula, with a higher occurrence at the Granada and El Arenosillo sites (the two closest points to the African continent and hence to the Saharan desert) (see also Toledano et al., 2007b; GuerreroRascado et al., 2009; Antón et al., 2012). For instance, the minimum values of $\alpha$ obtained for the Granada station during

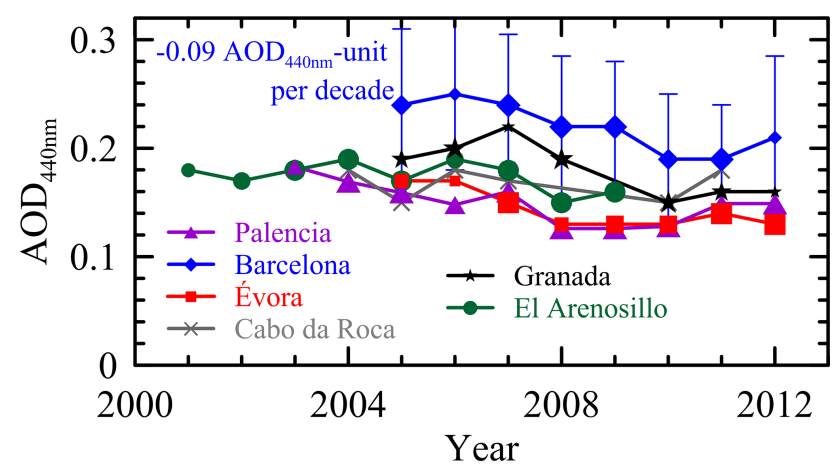

Figure 4. Yearly values of $\mathrm{AOD}_{440 \mathrm{~nm}}$ at the six sites: Barcelona (blue diamonds), Palencia (purple triangles), Évora (red squares), Cabo da Roca (grey crosses), Granada (black stars), and El Arenosillo (green circles). The text points out the statistically significant trend obtained. Vertical bars indicate the standard deviation of each yearly value at the Barcelona station. The larger the symbols, the larger amount of data points that year (e.g., the smallest symbols indicate cases between 100 and 150 points, while the largest symbols show years with $>250$ points).

summer months are linked to the higher likelihood of desert dust events (Valenzuela et al., 2012) because they are sometimes associated with high aerosol loads (Córdoba-Jabonero et al., 2011). These results corroborate the findings obtained by previous studies about desert dust events over the Iberian Peninsula (see, e.g., Lyamani et al., 2005; Toledano et al., 2007b; Cachorro et al., 2008).

The inter-annual change of aerosol load can be established over the last decade in the Iberian Peninsula. The yearly values of $\mathrm{AOD}_{440 \mathrm{~nm}}$ at the six sites are shown in Fig. 4. The geographical distribution of AOD throughout the Spanish geography is observed in the figure. The Barcelona site presents yearly values over $\sim 0.2$. Granada, El Arenosillo, and Cabo da Roca exhibit yearly means in the interval between 0.15 and 0.22, while the means for the Palencia and Évora sites are slightly lower, between 0.12 and 0.18 . Analyzing the six sites together, the year 2010 presents one of the minimum values of $\mathrm{AOD}_{440 \mathrm{~nm}}$, while the maximum averages seem to appear at the early 2000s. The different sampling of AOD measurements in the six sites can produce discrepancies because different events may or may not be captured in each database. In addition, possible technical problems and meteorological conditions (Cimel aerosol data are recorded under cloud-free skies) cause an unequal distribution through the year. Overall, summer is the season with the largest contribution of data, followed by spring, autumn, and winter. Looking at the years with a large sampling (> 200 days in at least four stations), 2005, 2007, and 2011, all the features mentioned above are corroborated for these particular years. The minimum of 2010 occurred when two southern sites (El Arenosillo and Cabo da Roca) did not have enough data to evaluate the yearly mean. Hence we cannot ensure that the 
apparent minimum of AOD recorded that year is linked to global-scale phenomena or to more local conditions at the other sites. During 2010, persistent negative phases of the North Atlantic Oscillation (NAO) and Quasi Biennal Oscillation (QBO) indices were observed (e.g., Steinbrecht et al., 2011), and the connection between air mass transport at global scale and particulate matter at the surface is proven by Pey et al. (2013) in the eastern Iberian Peninsula.

With respect to the temporal change, the evolution of these yearly values seems to be weak, which can be attributed to the large variability observed in the mean values, affected by different conditions and phenomena. In spite of this, the evaluation of the trend rates (see Section 3 for details) produces the more statistically significant change for the Barcelona site, where a decrease of the aerosol load of $0.09 \mathrm{AOD}_{440 \mathrm{~nm}^{-}}$ unit per decade is observed with a $p$ value of 0.02 . The AOD $_{440 \mathrm{~nm}}$ temporal change for the other sites exhibits $p$ values over 0.05 . Hence non-statistically significant results are obtained for the other sites. In spite of that, the sign of all temporal rates is negative. Hence a slight reduction of the aerosol load over the Iberian Peninsula can be deduced since 2000 from the annual values. This result obtained in southeastern Europe is in line with the long-term analysis of AOD series performed in northern Germany and Switzerland by Ruckstuhl et al. (2008). These authors highlight a strong decrease of aerosol load starting in 1985 and stabilizing since about 2000.

The reasons behind the decrease in the aerosol load since the early 2000s are a mix of anthropogenic and natural sources. As was reported by Aas et al. (2013), the particulate matter (PM) emissions in the Iberian Peninsula have decreased around $25 \%$ between 2000 and 2011. Furthermore, observational PM data in different Spanish sites have also shown a decreasing trend in the 2000s (e.g., Barmpadimos et al., 2012; Cusack et al., 2012; Pey et al., 2013; Bennouna et al., 2014; Mateos et al., 2014). This fact can be understood by the effect of the current economic crisis and the implementation of new environmental laws to control the pollution (e.g., Querol et al., 2014). In addition, recent studies have shown that natural aerosols have also decreased in the last decade. For instance, Gkikas et al. (2013) reported, using satellite AOD estimations, that strong and extreme desert dust episodes in the Mediterranean decreased in the period from 2000 to 2007 over land surfaces. This change is understood due to the low spring and summer frequencies in 2005 and 2007 and the high frequencies in 2000 and 2003. As shown by Pey et al. (2013), one possible reason behind this change is the atypical trajectories followed by the air masses emerging from northern Africa in the summers since 2006. Hence both columnar and surface aerosols have indicated a decrease in the aerosol load over the Iberian Peninsula, which has increased solar radiation levels reaching the surface in the 2000s (Mateos et al., 2014).

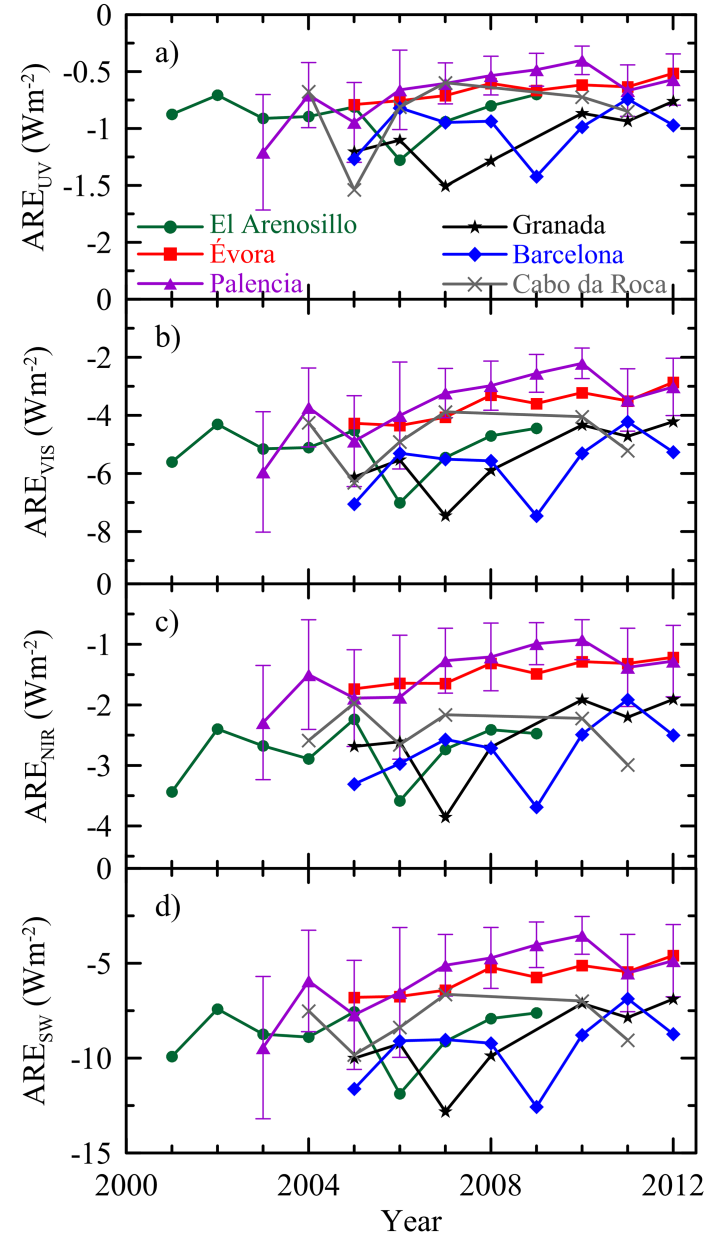

Figure 5. Evolution of yearly $\mathrm{ARE}_{\mathrm{UV}}$ (a), $\mathrm{ARE}_{\mathrm{VIS}}$ (b), $\mathrm{ARE}_{\mathrm{NIR}}$ (c), and $\mathrm{ARE}_{\mathrm{SW}}$ (d) at the six sites: Barcelona (blue diamonds), Palencia (purple triangles), Évora (red squares), Cabo da Roca (grey crosses), Granada (black stars), and El Arenosillo (green circles). Vertical bars indicate the standard deviation of each yearly value at the Palencia station.

\section{Inter-annual and intra-annual evolution of ARE}

From the daily data, the yearly ARE for each station and spectral range is evaluated to analyze the inter-annual changes (see Fig. 5). In spite of the high variability of the yearly values with large standard deviations (see the vertical bars for the Palencia station in the figure), the radiative effects of atmospheric aerosols have slightly declined over the last years. The patterns of ARE in the UV, VIS, NIR, and SW ranges are similar since the inter-annual changes are simultaneously observed in the four spectral intervals. With respect to the geographical distribution, the Barcelona and Granada sites exhibit the largest effects (more negative ARE), which is in line with the large values of $\mathrm{AOD}_{440} \mathrm{~nm}$ shown in Fig. 4. The weakest aerosol effect (less negative ARE) is observed in the Palencia and Évora sites, which is again linked to the lower yearly $\mathrm{AOD}_{440 \mathrm{~nm}}$. 


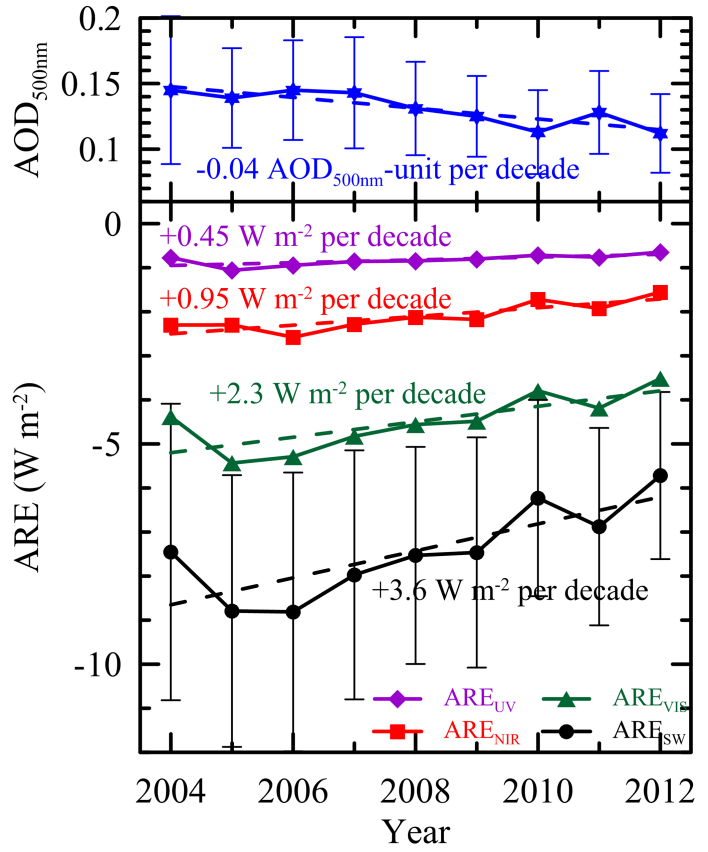

Figure 6. Evolution of annual $\mathrm{ARE}$ at the four spectral ranges (ARE $\mathrm{AV}_{\mathrm{U}}$ purple diamonds, $\mathrm{ARE}_{\mathrm{VIS}}$ red squares, $\mathrm{ARE}_{\mathrm{NIR}}$ green triangles, and $\mathrm{ARE}_{\mathrm{SW}}$ black circles) and $\mathrm{AOD}$ at $500 \mathrm{~nm}$ (blue stars), averaging the data from the six Iberian ground-based sites (only years with at least three sites considered). Dashed lines point out the linear trends (see text).

To establish the general behavior of the ARE over the whole Iberian Peninsula, the yearly values using the six ground-based stations are evaluated. Only those years with simultaneous measurements at three sites at least are considered in these averages; consequently, the time period is limited to 2004-2012. Figure 6 shows the evolution of the ARE and AOD at $500 \mathrm{~nm}$ for the entire peninsula. The decline of the AOD for this mean series produces a consequent decrease in the aerosol radiative effect at the four spectral ranges. The temporal trends of these yearly values are evaluated, and all the trends shown in Fig. 6 resulted in $p$ values between 0.004 and 0.03 . Overall, $\mathrm{ARE}_{\mathrm{SW}}$ over the Iberian Peninsula increased $3.6 \mathrm{~W} \mathrm{~m}^{-2}$ per decade $(p$ value $=0.028)$, while the aerosol reduced $0.04 \mathrm{AOD}_{500 \mathrm{~nm}^{-}}$ unit per decade ( $p$ value $=0.006$ ). Furthermore, this reduction in the radiative effects of the atmospheric aerosol over the Iberian Peninsula could partially contribute to the increase in the levels of SW radiation at the surface (the brightening phenomenon) in this region reported by, e.g., SanchezLorenzo et al. (2013) and Mateos et al. (2013b).

The yearly aerosol radiative effects over the entire peninsula are in the following ranges: $-1.1<\mathrm{ARE}_{\mathrm{UV}} \quad<-0.7 \mathrm{~W} \mathrm{~m}^{-2}, \quad-5.7<\mathrm{ARE}_{\mathrm{VIS}}$ $<-3.5 \mathrm{~W} \mathrm{~m}^{-2}, \quad-2.6<\mathrm{ARE}_{\mathrm{NIR}}<-1.6 \mathrm{~W} \mathrm{~m}^{-2}$, and $-8.8<\mathrm{ARE}_{\mathrm{SW}}<-5.7 \mathrm{~W} \mathrm{~m}^{-2}$. The larger contribution of the visible spectral region with respect to the whole solar

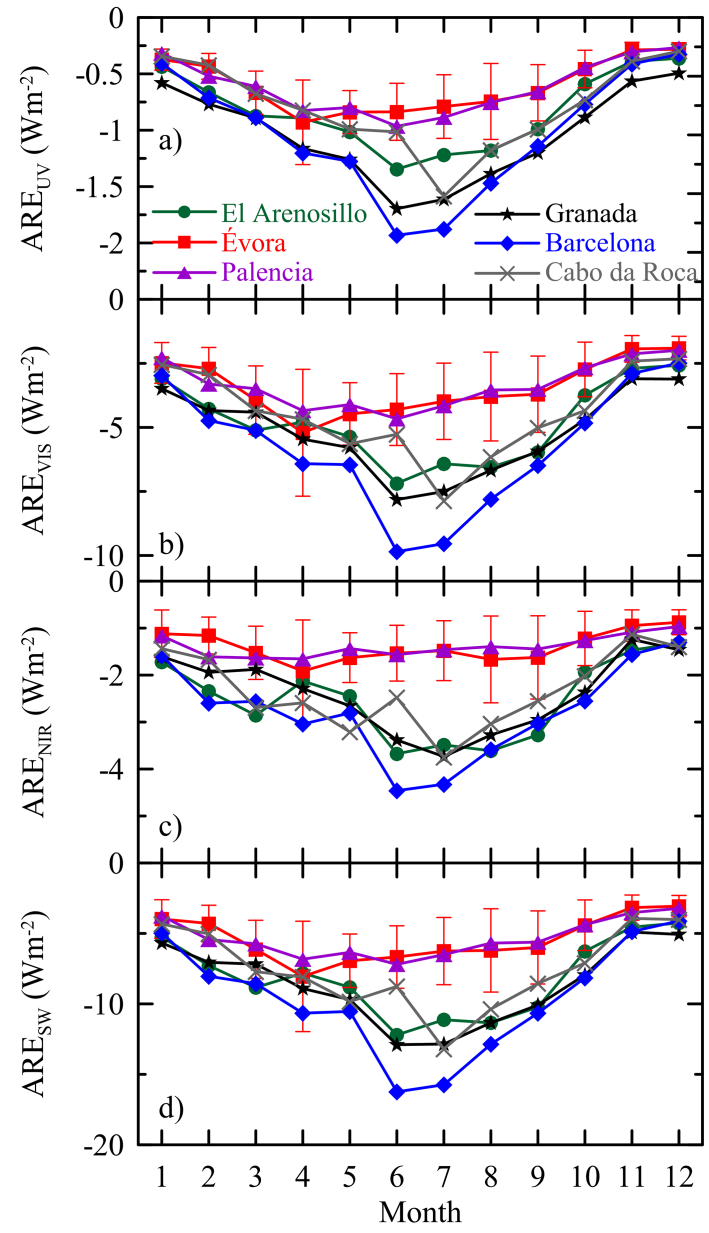

Figure 7. Annual cycle of $\mathrm{ARE}_{\mathrm{UV}}(\mathbf{a}), \mathrm{ARE}_{\mathrm{VIS}}$ (b), $\mathrm{ARE}_{\mathrm{NIR}}$ (c), and $\mathrm{ARE}_{\mathrm{SW}}$ (d) at the six sites: Barcelona (blue diamonds), $\mathrm{Pa}-$ lencia (purple triangles), Évora (red squares), Cabo da Roca (grey crosses), Granada (black stars), and El Arenosillo (green circles). Vertical bars point out the standard deviation of each monthly value at the Évora station.

spectrum was also noticed by Bush and Valero (2003); this is expected because the maximum of shortwave radiation is found in this interval. The relationship between ARE and $\mathrm{AOD}_{500 \mathrm{~nm}}$ is analyzed more in detail in Section 6, when the aerosol forcing efficiency is evaluated for each ground-based station.

In addition to the inter-annual changes, the intra-annual behavior is also analyzed. For this purpose, the annual cycle (12 monthly means) is evaluated for the six stations (see Fig. 7). A seasonal pattern is seen in $A_{R E}$ and AREVIS and therefore ARE $\mathrm{SW}$. However, ARE $\mathrm{NIR}_{\mathrm{N}}$ does not follow a seasonal pattern, particularly at the Évora and Palencia stations, given that $\mathrm{ARE}_{\mathrm{NIR}}$ remains nearly constant. Small differences among the six stations are observed in the annual cycle during the cold seasons. The aerosol radiative effects are stronger during summer months. This can be related to the higher likelihood of desert dust or biomass burn- 
ing events over the Iberian Peninsula in these months (e.g., Cachorro et al., 2008; Valenzuela et al., 2012), as was mentioned above. This is corroborated by the increase of the differences among the stations during the warm season, likely due to the variability in the impact of the desert dust episodes which strongly depend on the geographical location of each site. The higher occurrence of large aerosol loads during the warm seasons (see Fig. 1) can explain the more negative ARE during summer and spring in Fig. 7. For instance, the Barcelona station, with the largest values of $\mathrm{AOD}_{440 \mathrm{~nm}}$, is the bottom curve of each panel in Fig. 7. Furthermore, the influence of mineral dust aerosol (with high aerosol optical depth) during these months also causes strong radiative effects, as was also reported by previous studies (e.g., Cachorro et al., 2008; Guerrero-Rascado et al., 2009; Antón et al., 2011; Román et al., 2013; García et al., 2014). In addition, the bimodality of the monthly AOD climatology mentioned in Section 4 has its impact on the radiative effects. The annual AOD cycle (see Fig. 1, El Arenosillo site) causes the inverse monthly distribution of ARE with a first minimum in March. This effect is more clearly seen in $\mathrm{ARE}_{\mathrm{NIR}}$ and $\mathrm{ARE}_{\mathrm{SW}}$.

\section{Aerosol radiative forcing efficiency in different spectral ranges}

The daily AFE values are calculated (following the methodology described in Section 3) in all the spectral ranges. The AFE is a function of the aerosol optical properties, where both the aerosol particle size distribution and absorptive properties play a key role (e.g., Antón et al., 2011). As we assumed a fixed value of SSA $=0.90$ in the simulations with $\mathrm{AOD}_{440 \mathrm{~nm}}<0.15$ (see Table 2), the AFE is calculated only for those cases showing $\mathrm{AOD}_{440 \mathrm{~nm}}$ larger than 0.15 .

To identify the influence of SSA and $\alpha$ on AFE, this variable is calculated for several intervals of each aerosol property. Four categories of single scattering albedo at $675 \mathrm{~nm}$ are established in the calculation of the AFE: $1.0 \geq \mathrm{SSA}_{1}>0.95,0.95 \geq \mathrm{SSA}_{2}>0.90,0.90 \geq \mathrm{SSA}_{3}>0.85$, and $0.85 \geq \mathrm{SSA}_{4}>0.80$. Furthermore, aerosol size is classified in three intervals: $0 \leq \alpha_{1} \leq 1,1<\alpha_{2} \leq 1.5$, and $1.5<\alpha_{3} \leq 2$. Note that two intervals in the range of $\alpha$ larger than 1 have been considered-one for median particles and another for fine particles-because of the relevant importance of median size particle (continental or mixed aerosol aerosols types) over the Iberian Peninsula (see Fig. 3). Although the general classification between fine and coarse particles requires a more refined classification (Schuster et al., 2006; Prats et al., 2011), the more general intervals selected in this study are adequate to perform a study of the aerosol sizes at the six stations together.

Figure 8 shows the AFE obtained for the UV (AFE $\left.{ }_{U V}\right)$, VIS (AFE $\mathrm{VIS}_{\mathrm{V}}$ ), NIR (AFE $\mathrm{AIR}_{\mathrm{N}}$ ), and $\mathrm{SW}\left(\mathrm{AFE}_{\mathrm{SW}}\right)$ ranges for all these intervals. The threshold to evaluate the aver-

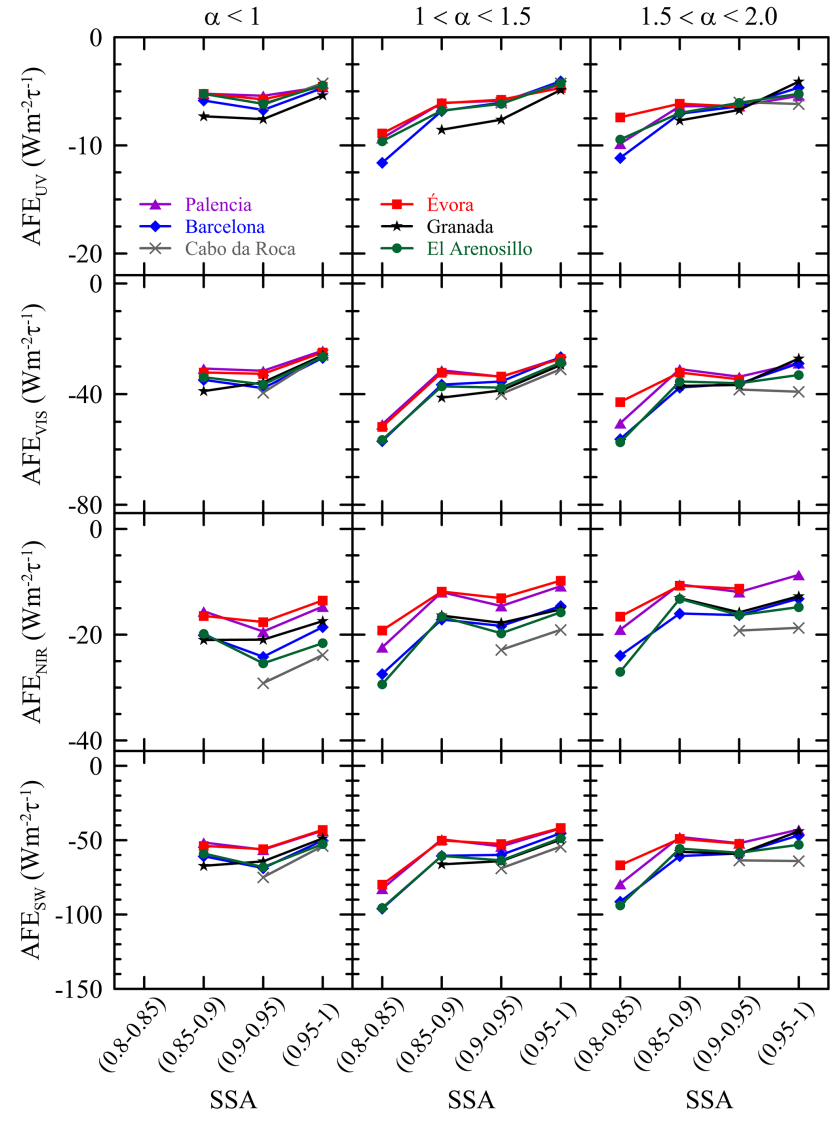

Figure 8. $\mathrm{AFE}_{\mathrm{UV}}, \mathrm{AFE}_{\mathrm{VIS}}, \mathrm{AFE}_{\mathrm{NIR}}$, and $\mathrm{AFE}_{\mathrm{SW}}$ against four groups of aerosol single scattering albedo and three intervals of $\alpha$ at the six sites: Barcelona (blue diamonds), Palencia (purple triangles), Évora (red squares), Cabo da Roca (grey crosses), Granada (black stars), and El Arenosillo (green circles).

age in each sub-interval is fixed at 10 data points. These figures show that the stronger the absorption by aerosols, the stronger their forcing efficiency. That is a decrease in the absolute values of the AFE for increasing SSA and for all particle sizes. In general, the groups of non-absorbing particles exhibit a good agreement among the six stations (see, for instance, AFE values in all the spectral ranges in the interval $1<\alpha \leq 1.5)$. Larger differences are obtained in the case of more absorbing aerosol particles. These can be understood because of the different types of aerosols presented over each site (see Sect. 4) and the different data points. The average AFE values over the whole Iberian Peninsula (considering the six stations together) are presented separately in Table 3 as a function of $\alpha$ and SSA. The role played by the aerosol size on AFE values is different in the three sub-intervals of the shortwave radiation. The $\mathrm{AFE}_{\mathrm{UV}}$ and $\mathrm{AFE}_{\mathrm{VIS}}$ are larger (in absolute value) for fine particles, while the opposite occurs in the case of $\mathrm{AFE}_{\mathrm{NIR}}$. As a result of these mixed effects, $\mathrm{AFE}_{\mathrm{SW}}$ also shows a decrease in its values with increasing $\alpha$, but this effect is weaker than for the visible and ultravio- 
Table 4. Daily forcing efficiencies at the surface by previous studies. Legend: desert dust (DD), continental-biomass burning (C-BB), and forest fires (FF).

\begin{tabular}{|c|c|c|c|c|c|c|}
\hline Reference & $\begin{array}{l}\text { Aerosol } \\
\text { Type }\end{array}$ & $\mathrm{AFE}_{X}$ & $\begin{array}{l}\text { Value } \\
\left.\text { (W } \mathrm{m}^{-2} \tau^{-1}\right)\end{array}$ & $\begin{array}{l}\text { Time } \\
\text { period }\end{array}$ & Region & More info. \\
\hline Díaz et al. (2007) & Mixed & $\mathrm{AFE}_{\mathrm{UV}}$ & -3 & July 2002 & Spain & $290-363 \mathrm{~nm}$ \\
\hline Meloni et al. (2005) & $\begin{array}{l}\text { DD } \\
\text { Mixed }\end{array}$ & $\mathrm{AFE}_{\mathrm{VIS}}$ & $\begin{array}{l}-28.4 \\
-45.6\end{array}$ & July 2002 & $\begin{array}{l}\text { Central } \\
\text { Mediterranean }\end{array}$ & \\
\hline Lyamani et al. (2006) & Mixed & $\mathrm{AFE}_{\mathrm{VIS}}$ & -75.8 & August 2003 & Spain & 2003 heat wave \\
\hline Di Biagio et al. (2010) & $\begin{array}{l}\text { DD } \\
\text { C-BB } \\
\text { Mixed }\end{array}$ & $\mathrm{AFE}_{\mathrm{SW}}$ & $\begin{array}{l}-68.9 \\
-59.0 \\
-94.9\end{array}$ & 2004-2007 & $\begin{array}{l}\text { Central } \\
\text { Mediterranean }\end{array}$ & At the equinox \\
\hline $\begin{array}{l}\text { Esteve et al. (2014) } \\
\text { Santos et al. (2008) }\end{array}$ & $\begin{array}{l}\text { Mixed } \\
\text { FF }\end{array}$ & $\begin{array}{l}\text { AFE }_{S W} \\
\text { AFE }_{S W}\end{array}$ & $\begin{array}{l}-139.0 \\
-113.0\end{array}$ & $\begin{array}{l}2003-2011 \\
2004-2005\end{array}$ & $\begin{array}{l}\text { Spain } \\
\text { Portugal }\end{array}$ & $\begin{array}{l}200 \text { cloud-free days } \\
\text { Absorbing aerosols }\end{array}$ \\
\hline di Sarra et al. (2011) & DD & $\mathrm{AFE}_{\mathrm{SW}}$ & -55 & $25-26 / 03 / 2010$ & $\begin{array}{l}\text { Central } \\
\text { Mediterranean }\end{array}$ & Strong event \\
\hline García et al. (2014) & $\mathrm{DD}$ & $\mathrm{AFE}_{\mathrm{SW}}$ & -59 & 2009-2012 & Canary Islands & 386 cloud-free days \\
\hline Costa et al. (2006) & $\mathrm{DD}$ & $\mathrm{AFE}_{\mathrm{SW}}$ & -116.9 & $7 / 04 / 2000$ & Korea & $\mathrm{SSA}=0.76$ \\
\hline Zhou et al. (2005) & DD & $\mathrm{AFE}_{\mathrm{SW}}$ & $-80 /-48$ & $\begin{array}{l}\text { Monthly aerosol } \\
\text { climatology }\end{array}$ & $\begin{array}{l}\text { North Africa and } \\
\text { Arabian Peninsula }\end{array}$ & $\begin{array}{l}\text { Depending on } \\
\text { surface albedo }\end{array}$ \\
\hline Saha et al. (2008) & $\begin{array}{l}\text { C-BB } \\
\text { Mixed }\end{array}$ & $\mathrm{AFE}_{S W}$ & $\begin{array}{l}-97.6 \\
-81.5\end{array}$ & 2005-2006 & French & $\begin{array}{l}0.7<\text { SSA }<0.8 \\
\text { Mediterranean }\end{array}$ \\
\hline Valenzuela et al. (2012) & DD & $\mathrm{AFE}_{S W}$ & -70 & 2005-2010 & Spain & \\
\hline
\end{tabular}

let parts. SSA exhibits a more dominant role. As previously observed, the most negative values are achieved for the most absorbing aerosols considered in this study (group 1 of SSA, see Table 3).

The average values of forcing efficiency obtained in this study (see Table 3) are in line with those found by other authors. Table 4 summarizes the results obtained by previous studies. It is difficult to assess some features in the comparison with previously reported AFE values because of the different aerosol types, time periods, and methods analyzed. Our study presents the evaluation of ARE with six long-term databases of aerosol properties. In spite of that, the values shown in Table 3 agree with those in Table 4, but the larger discrepancies are observed in the studies focusing on specific events. Our results match better with the results reported by, e.g., Zhou et al. (2005), Meloni et al. (2005), and Di Biagio et al. (2010). As was noticed by, e.g., Costa et al. (2004, 2006) and Di Biagio et al. (2010), AFE at the surface is larger (in absolute term) for aerosols characterized by smaller and absorbing particles. This result is corroborated by the findings shown in this study. Furthermore, as was pointed out by Di Biagio et al. (2010), the aerosol absorption is the dominant factor on AFE evaluated at the surface.

To evaluate the contribution of each spectral range with respect to the shortwave, the dependence of each AFE ra- tio (VIS to SW and NIR to SW) on SSA and $\alpha$ is shown in Fig. 9. The $\mathrm{AFE}_{\mathrm{VIS}} / \mathrm{AFE}_{\mathrm{SW}}$ and $\mathrm{AFE}_{\mathrm{NIR}} / \mathrm{AFE}_{\mathrm{SW}}$ ratios are shown in the figure because their contributions are the dominant. $\mathrm{AFE}_{\mathrm{UV}} / \mathrm{AFE}_{\mathrm{SW}}$ ratio can be obtained as $100 \%$ minus the sum of the percentage of the two other ranges. As expected, unsubstantial differences are observed in the behavior of the six stations considered in this study. The NIR contribution becomes more decisive for large particles $(\alpha<1)$. It is expected that larger particles interact more with the longer wavelengths, while the smaller particles interact more with the shorter wavelengths. The presence of large particles with low SSA (high absorption) leads to a reduction of the $\mathrm{AFE}_{\mathrm{NIR}} / \mathrm{AFE}_{\mathrm{SW}}$ ratio as well as an increase of the $\mathrm{AFE}_{\mathrm{VIS}} / \mathrm{AFE}$ Sw ratio. However, for non-absorbing (high SSA) large particles the $\mathrm{AFE}_{\mathrm{NIR}} / \mathrm{AFE}_{\mathrm{SW}}$ ratio increases, and the contributions of the visible and infrared parts become more similar (both $\sim 40-50 \%$ ). The difference between $\mathrm{AFE}_{\mathrm{VIS}} / \mathrm{AFE}_{\mathrm{SW}}$ and $\mathrm{AFE}_{\mathrm{NIR}} / \mathrm{AFE}_{\mathrm{SW}}$ increases for intermediate - fine particles. For these particles, the $\mathrm{AFE}_{\mathrm{VIS}} / \mathrm{AFE}_{\mathrm{SW}}$ ratio does not show a dependence on SSA. The smallest contribution of the NIR interval is $\sim 25 \%$ under strong absorbing aerosols and fine particles, while $\mathrm{AFE}_{\mathrm{VIS}} / \mathrm{AFE}_{\mathrm{SW}}$ is still over $60 \%$. For this case, the contribution of the ultraviolet range achieves a maximum of $\sim 15 \%$, being almost comparable with the near-infrared contribution. In summary, 


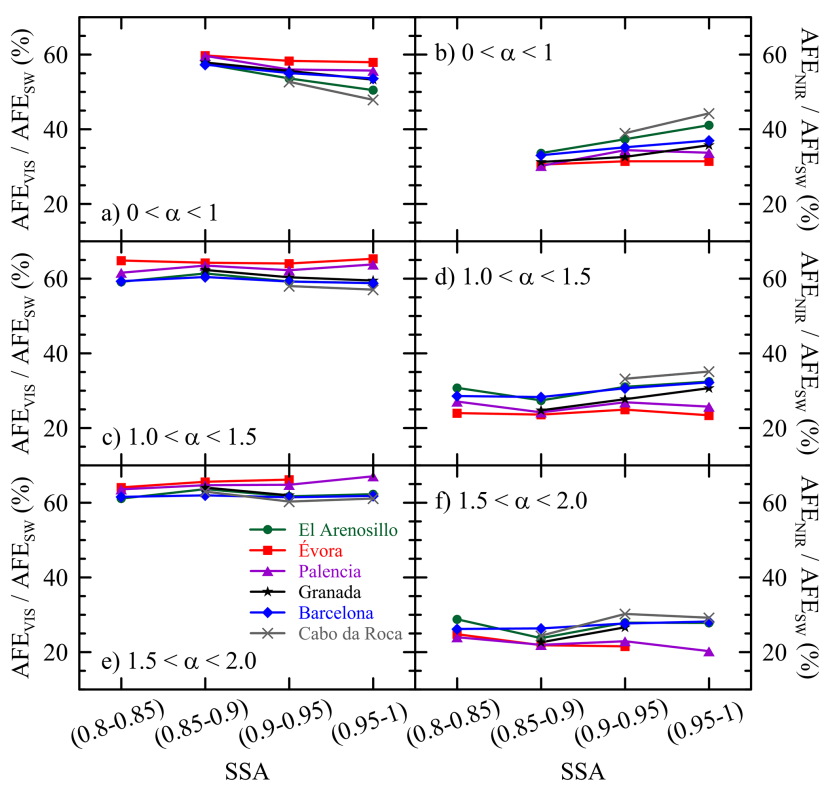

Figure 9. Dependence of $\mathrm{AFE}_{\mathrm{VIS}} / \mathrm{AFE}_{\mathrm{SW}}$ (a, c, e) and $\mathrm{AFE}_{\mathrm{NIR}} / \mathrm{AFE}_{\mathrm{SW}}(\mathbf{b}, \mathbf{d}, \mathbf{f})$ ratios on SSA for large, $0<\alpha<1(\mathbf{a}, \mathbf{b})$, medium, $1<\alpha<1.5(\mathbf{c}, \mathbf{d})$, and small, $1.5<\alpha<2(\mathbf{e}, \mathbf{f})$, particles at the six sites: Barcelona (blue diamonds), Palencia (purple triangles), Évora (red squares), Cabo da Roca (grey crosses), Granada (black stars), and El Arenosillo (green circles).

aerosol size determines the relevance of VIS-NIR ranges, while SSA plays a key role, particularly for large particles.

\section{Conclusions}

Six long-term data sets of aerosol properties over the Iberian Peninsula were analyzed and used as input in a radiative transfer model to simulate ultraviolet, visible, near-infrared, and shortwave radiation. The aerosol radiative effect (ARE) and aerosol forcing efficiency (AFE) were calculated. The main conclusions are as follows:

1. The AOD and $\alpha$ annual cycles over the six analyzed sites present high variability among them, emphasizing the inhomogeneity of the Iberian Peninsula due mainly to the different predominant aerosol types over each station. The Barcelona site presents the largest AOD values, although southern locations (the Granada and El Arenosillo sites) frequently exhibit daily mean AOD values exceeding 0.2 during the summer months. The $\alpha$-AOD classification scheme has shown that continental (mainly clean) is the predominant aerosol type over the Iberian Peninsula. However, maritime aerosols are also frequent at the Cabo da Roca, El Arenosillo, and Évora sites. Desert dust events are registered at the six sites, with the highest frequency at Granada and El Arenosillo; however, the most relevant feature is the south-north (decreasing) gradient of desert dust load which modulates the aerosol climatology over the Iberian Peninsula.

2. In the whole Iberian Peninsula, yearly $A_{R E}$ ranges between -1.1 and $-0.7 \mathrm{Wm}^{-2}$, ARE $\mathrm{VIS}$ ranges between -5.7 and $-3.6 \mathrm{~W} \mathrm{~m}^{-2}$, and $\mathrm{ARE}_{\mathrm{NIR}}$ ranges between -2.6 and $-1.6 \mathrm{~W} \mathrm{~m}^{-2}$. As a result, $\mathrm{ARE}_{\mathrm{SW}}$ is in the range of -8.8 to $-5.7 \mathrm{~W} \mathrm{~m}^{-2}$. The temporal changes of $\mathrm{ARE}_{\mathrm{UV}}, \mathrm{ARE}_{\mathrm{VIS}}, \mathrm{ARE}_{\mathrm{NIR}}$, and $\mathrm{ARE}_{\mathrm{SW}}$ exhibit positive statistically significant trends between 2004 and 2012. For instance, the change rate for $\mathrm{ARE}_{\mathrm{SW}}$ is $+3.6 \mathrm{~W} \mathrm{~m}^{-2}$ per decade (statistically significant at the $95 \%$ confidence level). This decrease in the aerosol radiative effects (since ARE values are negative) is in line with a slight AOD decrease over in the Iberian Peninsula in the last decade.

3. The intra-annual ARE cycle exhibits larger values during spring and summer when the occurrence of high aerosol loading episodes over the Iberian Peninsula is more frequent. In general, the annual AOD cycle is driven by the occurrence of Saharan dust events.

4. The AFE values at the six sites used in this study are in good agreement. Conditions of high $\alpha$ (small particle predominance) and low SSA (high absorption) lead to the largest negative AFE values. Overall, as an average for the Iberian Peninsula $\mathrm{AFE}_{\mathrm{UV}}=-6 \mathrm{~W} \mathrm{~m}^{-2} \tau^{-1}$, $\mathrm{AFE}_{\mathrm{VIS}}=-34 \mathrm{~W} \mathrm{~m}^{-2} \tau^{-1}, \quad \mathrm{AFE}_{\mathrm{NIR}}=-19$ $\mathrm{Wm}^{-2} \tau^{-1}$, and $\mathrm{AFE}_{\mathrm{SW}}=-59 \mathrm{~W} \mathrm{~m}^{-2} \tau^{-1}$.

5. The contribution of the ultraviolet, visible, and infrared spectral ranges to total shortwave aerosol forcing efficiency is governed by the aerosol type. In general, the visible part of the spectrum is the most dominant part. Non-absorbing large particles result in more even contribution of VIS and NIR intervals to the AFE, while the UV range shows a higher contribution in cases of absorbing fine particles. 
Table A1. Mean relative difference (RD) in the UV, VIS, NIR, and SW net fluxes if SSA $=0.90$ and $g=0.75$ are compared with different SSA and $g$ scenarios for different SZA values.

\begin{tabular}{lcccc}
\hline $\mathrm{SZA}$ & $\mathrm{RD}$ UV (\%) & $\mathrm{RD}_{\mathrm{VIS}}(\%)$ & $\mathrm{RD}_{\mathrm{NIR}}(\%)$ & $\mathrm{RD}_{\mathrm{SW}}(\%)$ \\
\hline 30 & \pm 3.4 & \pm 1.9 & \pm 0.9 & \pm 1.5 \\
\hline 60 & \pm 4.9 & \pm 3.0 & \pm 1.5 & \pm 2.4 \\
\hline
\end{tabular}

\section{Appendix A}

The two choices in the performance of radiative transfer simulations from the libRadtran code concerning aerosol properties are justified in this section.

First of all, as mentioned in the text, most of the data present $\mathrm{AOD}_{440 \mathrm{~nm}}<0.15(\sim 70 \%$ for the Palencia, Granada, and Évora sites). For these low values, SSA $=0.9$ and $g$ $=0.75$ are selected for the representativeness of the local aerosols in the six sites of study (e.g., Cachorro et al., 2010). To analyze possible uncertainties emerging from this choice, the radiative net fluxes are also evaluated for SSA and $g$ values covering the largest variety of aerosols observed in the Iberian Peninsula. Hence $\mathrm{SSA}_{1}=0.8, \mathrm{SSA}_{2}=1.0$, $g_{1}=0.65$, and $g_{2}=0.80$ are selected in this analysis. Four possibilities or scenarios are simulated mixing the two values of the aerosol properties. The radiation obtained in each scenario is compared with the assumed case of SSA $=0.9$ and $g=0.75$. The two optical properties are also fixed as non-wavelength-dependent in this analysis. The $\mathrm{AOD}_{440 \mathrm{~nm}}$ used is 0.15 , the worst scenario possible for these cases because the higher the AOD, the stronger the impact of aerosol properties. The simulations are performed for the four spectral ranges. Appendix Table A1 shows the mean relative difference observed for the four scenarios and two different SZAs $\left(30^{\circ}\right.$ and $\left.60^{\circ}\right)$. The assumption considered in this study causes, in the worst possible scenarios, errors in the ARE retrievals (obtained as the expanded errors from the radiative uncertainty) $<10 \%,<6 \%,<3 \%$, and $<5 \%$ for the UV, VIS, NIR, and SW ranges, respectively. As the cases with $\mathrm{AOD}_{440 \mathrm{~nm}}<0.15$ are the large majority of the Iberian Peninsula, they should be included in the study. The experimental retrievals of SSA and $g$ for these cases with low AOD present large uncertainties, and no reliable information can be used to verify our assumption. Hence the results of this sensitivity study are adequate. As the SSA influences the diffuse radiation, the worst results are obtained at large SZAs. The impact of $g$ on the net fluxes is very weak. In conclusion, the choice of SSA $=0.9$ and $g=0.75$ in a clean scenario $\left(\mathrm{AOD}_{440 \mathrm{~nm}}<0.15\right)$ is proven adequate for two reasons: (a) representativeness of the local aerosols which can be a mixture of different types, and (b) the low uncertainty produced in the simulations by SSA and $g$ under these conditions.

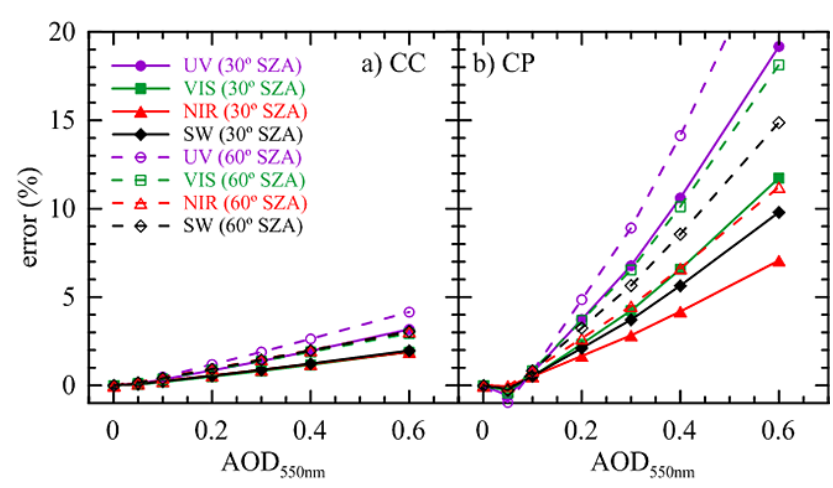

Figure A1. Dependence on aerosol load of the error committed when the optical properties are fixed in the different spectral ranges for two SZAs $\left(30^{\circ}\right.$ solid lines and symbols, and $60^{\circ}$ dashed lines and open symbols), and (a) continental clean (CC) and (b) continental polluted $(\mathrm{CP})$ aerosols.

The choice of fixed SSA and $g$ values within each of the spectral ranges (UV, VIS, and NIR) represented by the Cimel spectral measurements is also justified here. The aerosol models by Shettle (1989) included in the libRadtran code (see Mayer and Kylling, 2005) are used to evaluate the uncertainty of using this approximation. The continental clean aerosols (most common type in the Iberian Peninsula, see Fig. 3) and continental polluted aerosols (also very common, they present an extreme case of absorption) are tested in this analysis. The simulations are performed for the expected spectral behavior of SSA and $g$ following Shettle (1989) and the case of fixed properties in the UV (SSA and $g$ values at $440 \mathrm{~nm}$ ), VIS (SSA and $g$ values at $675 \mathrm{~nm}$ ), and NIR intervals (SSA and $g$ average of values at 870 and $1020 \mathrm{~nm}$ ). Appendix Fig. A1 presents the evolution of the relative error (considering as reference the net flux with the expected spectral dependence of aerosol properties) for several AOD values between aerosol-free and $\mathrm{AOD}_{550 \mathrm{~nm}}=0.6$. In the case of continental clean aerosols (Fig. A1a), the error of using our assumption is lower than $5 \%$ for all SZAs and spectral ranges. Therefore, as the large majority of aerosol particles are of this type, the methodology used and proposed in this study only introduces a relative error below $5 \%$ in the majority of the simulations. With respect to the continental polluted aerosols (Fig. A1b), the error increases, achieving a maximum around $20 \%$ for the UV range and very turbid conditions. For large AOD conditions in the Iberian Peninsula (e.g., $\mathrm{AOD}_{550 \mathrm{~nm}}=0.4$ ), but low frequency of occurrence in contrast to $\mathrm{AOD}_{440 \mathrm{~nm}}<0.15$, the error of the $\mathrm{SW}$ range is below $5 \%$. However, the UV range is more sensitive to our method and the error is around $15 \%$ at $\mathrm{SZA}=60^{\circ}$. As mentioned above, the errors are larger for large SZAs because of the possible interaction between absorption and scattering processes, resulting in diffuse radiation. The visible range is more sensitive to the spectral variations than the NIR interval, which exhibits a maximum error around $11 \%$ 
at $\mathrm{SZA}=60^{\circ}$ and $\mathrm{AOD}_{550 \mathrm{~nm}}=0.6$. The daily net radiative fluxes are also evaluated for the two aerosol types in order to quantify the uncertainty in the final simulated data used in this study. For the Palencia site (and the corresponding SZA evolution), a daily value for 20 June is simulated assuming TOC $=300 \mathrm{DU}$ and $\mathrm{PWC}=1 \mathrm{~cm}$. The results for the continental polluted case with $\mathrm{AOD}_{440 \mathrm{~nm}}=0.4$ exhibit differences between the spectral and fixed-band aerosol properties: 7.5, 5.3, 4.0, and $4.8 \%$ for the UV, VIS, NIR, and SW intervals, respectively. The relative errors for the same intervals with continental clean (and the same AOD value) are 1.9, 1.2, 1.4 , and $1.4 \%$, respectively. Therefore, the uncertainty due to fixed optical properties in each spectral range is dependent on the aerosol type, but the error caused can be considered acceptable. Since actual aerosols often present mixtures of different types, the uncertainty of using the theoretical spectral evolution for one type (given by an aerosol model) can also produce uncertainties which should be taken into account. Although other aerosol types are not tested in this analysis, a similar behavior can be expected. For instance, for the case of desert dust aerosols, Román et al. (2013) found a slight influence of spectral aerosol absorption properties on UV irradiance while analyzing a strong Saharan intrusion over the Granada site.
Therefore the two assumptions performed in the simulations of this study are adequate for the evaluation of net fluxes and aerosol radiative effects. The uncertainties that can be introduced in the daily values are acceptable being around or smaller than $5 \%$ for the net SW radiation. This uncertainty is usually achieved in clear-sky modeling (e.g., Mateos et al., 2013a). 
Acknowledgements. This work is supported by the Spanish Ministry of Science and Technology (currently MINECO) through projects CGL2010-18782, CSD2007-00067, CGL2011-29921C02-01, CGL2011-23413, CGL2011-24891, CGL2011-13085-E, CGL2011-13580-E， CGL2012-33576, and CGL2012-33576; FEDER (Programa Operacional Factores de Competitividade COMPETE). It is also supported by Portuguese funding through FCT - Fundação para a Ciência e a Tecnologia in the framework of project FCOMP-01-0124-FEDER-009303 (PTDC / CTE-ATM / 102142 / 2008); the Évora Geophysics Centre, Portugal, under the contract with FCT, PEst-OE/CTE/UI0078/2014; and the Andalusia Regional Government through projects P08- RNM-3568 and P10-RNM-6299. The research leading to these results has also received funding from the European Union Seventh Framework Programme (FP7/2007-2013) under grant agreement Nr. 262254 [ACTRIS]. Manuel Antón and Carlos Toledano thank Ministerio de Ciencia e Innovación and Fondo Social Europeo for the award of a postdoctoral grant (Ramón y Cajal). Mar Sorribas is thankful for the postdoctoral grant (Juan de la Cierva). We must specially thank the AERONET-GSFC, PHOTONS-LOA, and RIMA-GOA-UVa staff for their scientific and technical support. Ozone Monitoring Instrument (OMI) and Total Ozone Mapping Spectrometer (TOMS) ozone column data were obtained from the Giovanni online data system, developed and maintained by the NASA GES DISC.TEXT

Edited by: W. Lahoz

\section{References}

Aas, W., Espen Yttri, K., Stohl, A., Lund Myhre, C., Karl, M., Tsyro, S., Marečková, K., Wankmüller, R., Klimont, Z., Heyes, C., Alastuey, A., Querol, X., Pérez, N., Moreno, T., Lucarelli, F., Areskoug, H., Balan, V., Cavalli, F., Putaud, J. P., Cape J. N., Catrambone, M., Ceburnis, D., Conil, S., Gevorgyan, L., Jaffrezo, J. L., Hueglin, C., Mihalopoulos, N., Mitosinkova, M., Riffault, V., Sellegri, K., Spindler, G., Schuck, T., Pfeffer, U., Breuer, L., Adolfs, D., Chuntonova, L., Arabidze, M., and Abdulazizov, E.: Transboundary particulate matter in Europe Status report 2013, EMEP Report, 4/2013 (Ref. O-7726), ISSN: 15046109 (print), 1504-6192 (online), 2013.

Antón, M., Gil, J. E., Fernández-Gálvez, J., Lyamani, H., Valenzuela, A., Foyo-Moreno, I., Olmo, F. J., and AladosArboledas, L.: Evaluation of the aerosol forcing efficiency in the UV erythemal range at Granada, Spain, J. Geophys. Res., 116, D20214, doi:10.1029/2011JD016112, 2011.

Antón, M., Valenzuela, A., Cazorla, A., Gil, J. E., FernándezGálvez, J., Lyamani, H., Foyo-Moreno, I., Olmo, F. J., and Alados-Arboledas, L.: Global and diffuse shortwave irradiance during a strong desert dust episode at Granada (Spain), Atmos. Res., 118, 232-239, doi:10.1016/j.atmosres.2012.07.007, 2012.

Antón, M., Valenzuela, A., Mateos, D., Alados, I., Foyo-Moreno, I., Olmo, F.J., Alados-Arboledas, L.: Lonwave aerosol radiative effects during an extreme desert dust event in Southeastern Spain, Atmos. Res., 148, 18-23, doi:10.1016/j.atmosres.2014.05.022, 2014

Barja, B. and Antuña, J. C.: The effect of optically thin cirrus clouds on solar radiation in Camagüey, Cuba, Atmos. Chem. Phys., 11, 8625-8634, doi:10.5194/acp-11-8625-2011, 2011.
Barmpadimos, I., Keller, J., Oderbolz, D., Hueglin C., and Prèvôt, A. S. H.: One decade of parallel fine $\left(\mathrm{PM}_{2.5}\right)$ and coarse $\left(\mathrm{PM}_{10}-\mathrm{PM}_{2.5}\right)$ particulate matter measurements in Europe: trends and variability, Atmos. Chem. Phys. 12, 3189-3203, doi:10.5194/acp-12.3189-2012, 2012.

Bennouna, Y., Cachorro, V., Toledano, C., Berjón, A., Prats, N., Fuertes, D., Gonzalez, R., Rodrigo, R., Torres, B., and de Frutos, A.: Comparison of atmospheric aerosol climatologies over southwestern Spain derived from AERONET and MODIS, Remote Sens. Environ., 115, 1272-1284, 2011.

Bennouna, Y. S., Cachorro, V., Burgos, M. A., Toledano, C., Torres, B., and de Frutos, A.: Relationships between columnar aerosol optical properties and surface particulate matter observations in north-central Spain from long-term records (2003-2011), Atmos. Meas. Tech. Discuss., 7, 5829-5882, doi:10.5194/amtd-7-58292014, 2014.

Boucher, O., Randall, D., Artaxo, P., Bretherton, C., Feingold, G., Forster, P., Kerminen, V.-M., Kondo, Y., Liao, H., Lohmann, U., Rasch, P., Satheesh, S.K., Sherwood, S., Stevens, B., and Zhang, X. Y.: Clouds and aerosols, in: Climate Change 2013: The Physical Science Basis, Contribution of Working Group I to the Fifth Assessment Report of the Intergovernmental Panel on Climate Change, edited by: Stocker, T. F., Qin, D., Plattner, G.-K., Tignor, M., Allen, S. K., Doschung, J., Nauels, A., Xia, Y., Bex, V., and Midgley, P. M., Cambridge University Press, 571-657, 2013.

Bush, B. C. and Valero, F. P. J.: Surface aerosol radiative forcing at Gosan during the ACE-Asia campaign, J. Geophys. Res., 108, 8660, doi:10.1029/2002JD003233, 2003.

Cachorro, V. E., Toledano, C., Prats, N., Sorribas, M., Mogo, S., Berjón, A., Torres, B., Rodrigo, R., de la Rosa, J., and De Frutos, A. M.: The strongest desert dust intrusion mixed with smoke over the Iberian Peninsula registered with Sun photometry, J. Geophys. Res., 113, D14S04, doi:10.1029/2007JD009582, 2008.

Cachorro, V. E., Toledano, C., Antón, M., Berjón, A., de Frutos, A., Vilaplana, J. M., Arola, A., and Krotkov, N. A.: Comparison of UV irradiances from Aura/Ozone Monitoring Instrument (OMI) with Brewer measurements at El Arenosillo (Spain) - Part 2: Analysis of site aerosol influence, Atmos. Chem. Phys., 10, 11867-11880, doi:10.5194/acp-10-11867-2010, 2010.

Collaud Coen, M., Andrews, E., Asmi, A., Baltensperger, U., Bukowiecki, N., Day, D., Fiebig, M., Fjaeraa, A. M., Flentje, H., Hyvärinen, A., Jefferson, A., Jennings, S. G., Kouvarakis, G., Lihavainen, H., Lund Myhre, C., Malm, W. C., Mihapopoulos, N., Molenar, J. V., O’Dowd, C., Ogren, J. A., Schichtel, B. A., Sheridan, P., Virkkula, A., Weingartner, E., Weller, R., and Laj, P.: Aerosol decadal trends - Part 1: In-situ optical measurements at GAW and IMPROVE stations, Atmos. Chem. Phys., 13, 869894, doi:10.5194/acp-13-869-2013, 2013.

Córdoba-Jabonero, C., Sorribas, M., Guerrero-Rascado, J.L., Adame, J.A., Hernández, Y., Lyamani, H., Cachorro, V., Gil, M., Alados-Arboledas, L., Cuevas, E., and de la Morena, B.: Synergetic monitoring of Saharan dust plumes and potential impact on surface: a case study of dust transport from Canary Islands to Iberian Peninsula, Atmos. Chem. Phys., 11, 3067-3091, doi:10.5194/acp-11-3067-2011, 2011.

Costa, M. J., Levizzani, V., and Silva, A. M.: Aerosol Characterization and Direct Radiative Forcing Assessment over the Ocean, Part II: Application to Test Cases and Validation, J. Appl. Meteor., 43, 1818-1833, doi:10.1175/JAM2157.1, 2004. 
Costa, M. J., Sohn, B. J., Levizzani, V., and Silva, A. M.: Radiative forcing of Asian dust determined from the synergized GOME and GMS satellite data - a case study, J. Meteorol. Soc. Jpn., 84, 85-95, doi:10.2151/jmsj.84.85, 2006.

Cusack, M., Alastuey, A., Pérez, N., Pey, J., and Querol, X.: Trends of particulate matter $\left(\mathrm{PM}_{2.5}\right)$ and chemical composition at a regional site in the Western Mediterranean over the last nine years (2002-2010), Atmos. Environ, 12, 8341-8357, doi:10.5194/acp12-8341-2012, 2012.

de Miguel, A., Mateos, D., Bilbao, J., and Román, R.: Sensitivity analysis of ratio between ultraviolet and total shortwave solar radiation to cloudiness, ozone, aerosols and precipitable water, Atmos. Res., 102, 136-144, doi:10.1016/j.atmosres.2011.06.019, 2011.

Di Biagio, C., di Sarra, A., Meloni, D., Monteleone, F., Piacentino, S., and Sferlazzo, D.: Measurements of mediterranean aerosol radiative forcing and influence of the single scattering albedo, J. Geophys. Res., 114, D06211, doi:10.1029/2008JD011037, 2009.

Di Biagio, C., di Sarra, A., and Meloni, D.: Large atmospheric shortwave radiative forcing by Mediterranean aerosols derived from simultaneous ground-based and spaceborne observations and dependence on the aerosol type and single scattering albedo, J. Geophys. Res., 115, D10209, doi:10.1029/2009JD012697, 2010.

di Sarra, A., Pace, G, Meloni, D., De Silvestri, L., Piacentino, S., and Monteleone, F.: Surface shortwave radiative forcing of different aerosol types in the Mediterranean, Geophys. Res. Lett., 35, L02714, doi:10.1029/2007GL032395, 2008.

di Sarra, A., Di Biagio, C., Meloni, D., Monteleone, F., Pace, G., Pugnaghi, S., and Sferlazzo, D.: Shortwave and longwave radiative effects of the intense Saharan dust event of 25-26 March 2010 at Lampedusa (Mediterranean Sea), J. Geophys. Res., 116, D23209, doi:10.1029/2011JD016238, 2011.

Díaz, A. M., García, O. E., Díaz, J. P., Expósito, F. J., Utrillas, M. P., Martínez-Lozano, J. A., Alados-Arboledas, L., Olmo, F. J., Lorente, J., Cachorro, V., Horvath, H., Labajo, A., Sorribas, M., Vilaplana, J. M., Silva, A. M., Elias, T., Pujadas, M., Rodrigues, J. A., and González, J. A.: Aerosol radiative forcing efficiency in the UV region over southeastern Mediterranean: VELETA2002 campaign, J. Geophys. Res., 112, D06213, doi:10.1029/2006JD007348, 2007.

Dubovik, O. and King, M. D.: A flexible inversion algorithm for retrieval of aerosol optical properties from Sun and sky radiance measurements, J. Geophys. Res., 105, 20673-20696, 2000.

Dubovik, O., Smirnov, A., Holben, B. N., King, M. D., Kaufman, Y. J., Eck, T. F., and Slutsker, I.: Accuracy assessments of aerosol optical properties retrieved from Aerosol Robotic Network (AERONET) Sun and sky radiance measurements, J. Geophys. Res., 105, 9791-9806, 2000.

Dubovik, O., Sinyuk, A., Lapynok, T., Holben, B. N., Mischenko, M., Yang, P., Eck, T. F., Volten, H., Muñoz, O., Veihelmann, B., van der Zande, W. J., Leon, J. F., Sorokin, M., and Slutsker, I.: Application of spheroid models to account for aerosol particle nonsphericity in remote sensing of desert dust, J. Geophys. Res., 111, D11208, 2006.

Esteve, A. R., Estellés, V., Utrillas, M. P., and MartínezLozano, J. A.: Analysis of the aerosol radiative forcing over a Mediterranean urban coastal site, Atmos. Res., 137, 194-204, doi:10.1016/j.atmosres.2013.10.009, 2014.

Foyo-Moreno, I., Alados, I., Antón, M., Fernández-Gálvez, J., Cazorla, A., and Alados-Arboledas, L.: Estimating aerosol characteristics from solar irradiance measurements at an urban location in Southeastern Spain, J. Geophys. Res. Atmos., 119, 18451859, doi:10.1002/2013JD020599, 2014.

García, O. E., Díaz, A. M., and Expósito, F. J.: Validation of AERONET estimates of atmospheric solar fluxes and aerosol radiative forcing by ground-based broadband measurements, J. Geophys. Res., 113, D21207, doi:10.1029/2008JD010211, 2008.

García, R. D., García, O. E., Cuevas, E., Cachorro, V. E., RomeroCampos, P. M., Ramos, R., and de Frutos, A. M.: Solar radiation measurements compared to simulations at the BSRN Izaña station: mineral dust radiative forcing and efficiency study, J. Geophys. Res.-Atmos., 119, 179-194, doi:10.1002/2013JD020301, 2014.

Gkikas, A., Hatzianastassiou, N., Mihalopoulos, N., Katsoulis, V., Kazadzis, S., Pey, J., Querol, X., and Torres, O.: The regime of intense desert dust episodes in the Mediterranean based on contemporary satellite observations and ground measurements, Atmos. Chem. Phys., 13, 12135-12154, doi:10.5194/acp-1312135-2013, 2013.

Guerrero-Rascado, J. L., Olmo, F. J., Avilés-Rodríguez, I., NavasGuzmán, F., Pérez-Ramírez, D., Lyamani, H., and Alados Arboledas, L.: Extreme Saharan dust event over the southern Iberian Peninsula in september 2007: active and passive remote sensing from surface and satellite, Atmos. Chem. Phys., 9, 84538469, doi:10.5194/acp-9-8453-2009, 2009.

Gueymard, C.: The sun's total and spectral irradiance for solar energy applications and solar radiation models, Sol. Energy, 76, 423-453, 2004.

Hansen, J. E., Sato, M., Lacis, A., Ruedy, R., Tegen, I., and Matthews, E.: Climate forcings in the industrial era, P. Natl. Acad. Sci. USA, 95, 12753-12758, doi:10.1073/pnas.95.22.12753, 1998.

Hatzianastassiou, N., Katsoulis, B., and Vardavas, I.: Global distribution of aerosol direct radiative forcing in the ultraviolet and visible arising under clear skies, Tellus B, 56, 51-71, doi:10.1111/j.1600-0889.2004.00085.x, 2004.

Hess, M., Koepke, P., and Schult, I.: Optical properties of aerosols and clouds: the software package OPAC, B. Am. Meteorol. Soc., 79, 831-844, 1998.

Holben, B. N., Eck, T. F., Slutsker, I., Tanré, D., Buis, J. P., Setzer, A., Vermote, E., Reagan, J. A., Kaufman, Y. J., Nakajima, T., Lavenu, F., Jankowiak, I., and Smirnov, A.: AERONET - a federated instrument network and data archive for aerosol characterization, Remote Sens. Environ., 66, 1-16, 1998.

Horvath, H., Alados Arboledas, L., Olmo, F. J., Jovanovic, O., Gangl, M., Kaller, W., Sánchez, C., Sauerzopf, H., and Seidl, S.: Optical characteristics of the aerosol in Spain and Austria and its effect on radiative forcing, J. Geophys. Res., 107, 4386, doi:10.1029/2001JD001472, 2002.

Jayaraman, A., Lubin, D., Ramachandran, S., Ramanathan, V., Woodbridge, E., Collins, W. D., and Zalpuri, K. S.: Direct observations of aerosol radiative forcing over the tropical Indian Ocean during the Janauary-February 1996 preINDOEX cruise, J. Geophys. Res., 103, 13827-13836, doi:10.1029/98JD00559, 1998. 
Kazadzis, S., Kouremeti, N., Bais, A., Kazantzidis, A., and Meleti, C.: Aerosol forcing efficiency in the UVA region from spectral solar irradiance measurements at an urban environment, Ann. Geophys., 27, 2515-2522, doi:10.5194/angeo-272515-2009, 2009.

Lucht, W. and Roujean, J. L.: Consideration in parametric modelling of BRDF and albedo from multi-angular satellite sensors observations, Remote Sens. Rev., 18, 343-379, 2000.

Lyamani, H., Olmo, F. J., and Alados-Arboledas, L.: Saharan dust outbreak over southeastern Spain as detected by sun photometer, Atmos. Environ., 39, 7276-7284, doi:10.1016/j.atmosenv.2005.09.011, 2005.

Lyamani, H., Olmo, F. J., Alcántara, A., and Alados-Arboledas, L.: Atmospheric aerosols during the 2003 heat wave in southeastern Spain II: microphysical columnar properties and radiative forcing, Atmos. Environ., 40, 6465-6476, doi:10.1016/j.atmosenv.2006.04.047, 2006.

Mallet, M., Dubovik, O., Nabat, P., Dulac, F., Kahn, R., Sciare, J., Paronis, D., and Léon, J. F.: Absorption properties of Mediterranean aerosols obtained from multi-year ground-based remote sensing observations, Atmos. Chem. Phys., 13, 9195-9210, doi:10.5194/acp-13-9195-2013, 2013.

Mateos, D., Antón, M., Sanchez-Lorenzo, A., Calbó, J., and Wild, M.: Long-term changes in the radiative effects of aerosols and clouds in a mid-latitude region (1985-2010), Global Planet. Change, 111, 288-295, doi:10.1016/j.gloplacha.2013.10.004, 2013a.

Mateos, D., Antón, M., Valenzuela, A., Cazorla, A., Olmo, F. J., and Alados-Arboledas, L.: Short-wave radiative forcing at the surface for cloudy systems at a midlatitude site, Tellus B, 65, 21069, doi:10.3402/tellusb.v65i0.21069, 2013b.

Mateos, D., Sanchez-Lorenzo, A., Antón, M., Cachorro, V.E., Calbó, J., Costa, M.J., Torres, B., and Wild, M.: Quantifying the respective roles of aerosols and clouds in the strong brightening since the early 2000s over the Iberian Peninsula, J. Geophys. Res. Atmos., 119, 10382-10393, doi:10.1002/2014JD022076, 2014.

Mayer, B. and Kylling, A.: Technical note: The libRadtran software package for radiative transfer calculations - description and examples of use, Atmos. Chem. Phys., 5, 1855-1877, doi:10.5194/acp-5-1855-2005, 2005.

Meloni, D., di Sarra, A., DeLuisi, J., Di Iorio, T., Fiocco, G., Junkerman, W., and Pace, G.: Tropospheric aerosols in the Mediterranean: 2. Radiative effects through model simulations and measurements, J. Geophys. Res., 108, 4317, doi:10.1029/2002JD002807, 2003.

Meloni, D., di Sarra, A., Di Iorio, T., and Fiocco, G.: Influence of the vertical profile of Saharan dust on the visible direct radiative forcing, J. Quant. Spectrosc. Ra., 93, 397-413, 2005.

Moody, E. G., King, M. D., Platnick, S., Schaaf, C. B., and Gao, F.: Spatially complete global spectral surface albedos: value-added datasets derived from Terra MODIS land products, IEEE T. Geosci. Remote, 43, 144-158, 2005.

Navas-Guzmán, F., Bravo-Aranda, J. A., Guerrero-Rascado, J. L., Granados-Muñoz, M. J., and Alados-Arboledas, L.: Statistical analysis of aerosol optical properties retrieved by Raman lidar over Southeastern Spain, Tellus B, 65, 21234, doi:10.3402/tellusb.v65i0.21234, 2013.

Nikitidou, E., Kazantzidis, A., De Bock, V., and De Backer, H.: The aerosol forcing efficiency in the UV region and the estimation of single scattering albedo at a typical West European site, Atmos. Environ., 69, 313-320, doi:10.1016/j.atmosenv.2012.12.035, 2013.

Obregón, M. A., Pereira, S., Wagner, F., Serrano, A., Cancillo, M. L., and Silva, A. M.: Regional differences of column aerosol parameters in western Iberian Península, Atmos. Environ., 62, 208-219, doi:10.1016/j.atmosenv.2012.08.016, 2012.

Pace, G., di Sarra, A., Meloni, D., Piacentino, S., and Chamard, P.: Aerosol optical properties at Lampedusa (Central Mediterranean). 1. Influence of transport and identification of different aerosol types, Atmos. Chem. Phys., 6, 697-713, doi:10.5194/acp-6-697-2006, 2006.

Panicker, A. S., Pandithurai, G., Safai, P. D., and Kewat, S.: Observations of enhanced aerosol longwave radiative forcing over an urban environment, Geophys. Res. Lett., 35, L04817, doi:10.1029/2007GL032879, 2008.

Pérez-Ramírez, D., Aceituno, J., Ruiz, B., Olmo, F.J., and AladosArboledas, L.: Development and calibration of a star photometer to measure the aerosol optical depth: Smoke observations at a high mountain site, Atmos. Environ, 42, 2733-2738, 2008.

Pey, J., Querol, X, Alastuey, A., Forastiere, F, and Stafoggia, M. African dust outbreaks over the Mediterranean Basin during 2001-2011: $\mathrm{PM}_{10}$ concentrations, phenomenology and trends, and its relation with synoptic and mesoscale meteorology, Atmos. Chem. Phys., 13, 1395-1410, doi:10.5194/acp-13-13952013, 2013.

Prats, N., Cachorro, V. E., Berjón, A., Toledano, C., and De Frutos, A. M.: Column-integrated aerosol microphysical properties from AERONET Sun photometer over south-western Spain. Atmos. Chem. Phys. 11, 12353-12547, doi:10.5194/acpd-1112353-2011, 2011.

Querol, X., Alastuey, A., Pandolfi, M., Reche, C., Pérez, N., Minguillón, M. C., Moreno, T., Viana, M., Escudero, M., Orio, A., Pallarés, M., and Reina, F.: 2001-2012 trends of air quality in Spain, Sci. Total Environ., 490, 957-969, 2014. Rajeev, K., and Ramanathan, V.: Direct observations of clearsky aerosol radiative forcing from space during the Indian Ocean Experiment, J. Geophys. Res., 106, 17,221-17,235, doi:10.1029/2000JD900723, 2001.

Reche, C., Viana, M., Moreno, T., Querol, X., Alastuey, A., Pey, J., Pandolfi, M., Prèvôt, A., Mohr, C., Richard, A., Artiñano, B., Gomez-Moreno, F.J., and Cots, N.: Peculiarities in atmospheric particle number and size-resolved speciation in an urban area in the western Mediterranean: Results from the DAURE campaign, Atmos. Environ, 45, 5282-5293, doi:10.1016/j.atmosenv.2011.06.059, 2011.

Román, R., Antón, M., Valenzuela, A., Gil, J. E., Lyamani, H., de Miguel, A., Olmo, F. J., Bilbao, J., and Alados-Arboledas, L.: Evaluation of the desert dust effects on global, direct, and diffuse spectral ultraviolet irradiance, Tellus B, 65, 19578, doi:10.3402/tellusb.v65i0.19578, 2013.

Román, R., Bilbao, J., and de Miguel, A.: Solar radiation simulations in the Iberian Peninsula: Accuracy and sensitivity to uncertainties in inputs of a radiative transfer model, J. Quant. Spectrosc. Ra., 145, 95-109, 2014.

Ruckstuhl, C., Philipona, R., Behrens, K., Coen, M. C., Dürr, B., Heimo, A., Mätzler, C., Nyieki, S., Ohmura, A., Vuilleumier, L., Weller, M., Wehrli, C., and Zelenka, A.: Aerosol and cloud 
effects on solar brightening and the recent rapid warming, Geophys. Res. Lett., 35, L12708, doi:10.1029/2008GL034228, 2008.

Saha, A., Mallet, M., Roger, J. C., Dubuisson, P., Piazzola, J., and Despiau, S.: One year measurements of aerosol optical properties over an urban coastal site: effect on local direct radiative forcing, Atmos. Res., 90, 195-202, doi:10.1016/j.atmosres.2008.02.003, 2008.

Sanchez-Lorenzo, A., Calbó, J., and Wild, M.: Global and diffuse solar radiation in Spain: building a homogeneous dataset and assessing trends, Global Planet. Change, 100, 343-352, doi:10.1016/j.gloplacha.2012.11.010, 2013.

Santos, D., Costa, M. J., and Silva, A. M.: Direct SW aerosol radiative forcing over Portugal, Atmos. Chem. Phys., 8, 5771-5786, doi:10.5194/acp-8-5771-2008, 2008.

Schuster, G. L., Dubovik, O., and Holben, B. N.: Angstrom exponent and bimodal aerosol size distributions, J. Geophys. Res., 111, D07207, doi:10.1029/2005JD006328, 2006.

Sen, P. K.: Estimates of the regression coefficient based on Kendall's tau, J. Am., Stat. Assoc., 63, 1379-1389, 1968.

Shettle, E. P.: Models of aerosols, clouds and precipitation for atmospheric propagation studies, paper presented at Conference on Atmospheric Propagation in the UV, Visible, IR and MM-Region and Related System Aspects, NATO Adv. Group for Aerosp. Res. and Dev., Copenhagen, 1989.

Stamnes, K., Tsay, S. C., Wiscombe, W., and Laszlo, I.: DISORT, a General-Purpose Fortran Program for Discrete-OrdinateMethod Radiative Transfer in Scattering and Emitting Layered Media: Documentation of Methodology, Tech. rep., Dept. of Physics and Engineering Physics, Stevens Institute of Technology, Hoboken, NJ 07030, 2000.
Steinbrecht, W., Köhler, U., Claude, H., Weber, M., Burrows, J. P., and van $\operatorname{der}$ A, R. J.: Very high ozone columns at northern mid-latitudes in 2010, Geophys Res Lett, 38, L06803, doi:10.1029/2010GL046634, 2011.

Toledano, C., Cachorro, V. E., Berjon, A., de Frutos, A. M., Sorribas, M., de la Morena, B., and Goloub, P.: Aerosol optical depth and Ångström exponent climatology at El Arenosillo AERONET site (Huelva, Spain), Q. J. Roy. Meter. Soc., 133, 795-807, 2007a.

Toledano, C., Cachorro, V. E., de Frutos, A. M., Sorribas, M., Prats, N., and de la Morena, B.: Inventory of African desert dust events over the southwestern Iberian Peninsula in 2000-2005 with an AERONET Cimel Sun photometer, J. Geophys. Res., 112, D21201, doi:10.1029/2006JD008307, 2007b.

Valenzuela, A., Olmo, F. J., Lyamani, H., Antón, M., Quirantes, A., and Alados-Arboledas, L.: Aerosol radiative forcing during African desert dust events (2005-2010) over Southeastern Spain, Atmos. Chem. Phys., 12, 10331-10351, doi:10.5194/acp-1210331-2012, 2012.

Zhou, M., Yu, H., Dickinson, R. E., Dubovik, O., and Holben, B. N.: A normalized description of the direct effect of key aerosol types on solar radiation as estimated from Aerosol Robotic Network aerosols and Moderate Resolution Imaging Spectroradiometer albedos, J. Geophys. Res., 110, D19202, doi:10.1029/2005JD005909, 2005. 